\title{
RELATÓRIO DAS REFERÊNCIAS CULTURAIS E ARQUEOLÓGICAS DA ÁREA DE ABRANGÊNCIA DO SISTEMA ADUTOR SERIDÓ - TRECHO PARELHAS / CARNAÚBA DOS DANTAS - RN - BRASIL
}

\section{Marília Perazzo *}

Carlos Rios *
* Docentes do Departamento de Arqueologia da Universidade Federal de Pernambuco-UFPE.
RESUMO: O presente relatório versa sobre a elaboração do Inventário de Referências Culturais das comunidades que estão no entorno do Sistema adutor Seridó - Parelhas / Carnaúba dos Dantas - RN. A elaboração do Inventário tomou como base as atividades de Prospecção Amostral Estratificada, não interventiva, caracterizada pela inspeção de áreas com maior probabilidade de identificar vestígios arqueológicos, bem como da catalogação dos bens de natureza cultural identificados nos municípios de Parelhas e Carnaúba dos Dantas - RN. As atividades realizadas na ADA, AID e Alll, e catalogação dos bens inventariados das comunidades do entorno da Adutora permitiram cadastrar, junto ao IPHAN, 56 sítios arqueológicos bem como o 9 patrimônios edificados nas áreas afetas a Adutora.

Palavras-chave: Patrimônio Cultural, Sítios Arqueológicos, Rio Grande Do Norte

ABSTRACT: This report is about the elaboration of the Cultural References Inventory of the communities that are in the surroundings of the Seridó - Parelhas / Carnaúba dos Dantas - RN pipeline. The elaboration of the Inventory was based on, non - interventional, Stratified Sampling Prospecting, characterized by the inspection of areas most likely to identify archaeological remains, as well as the cataloging of cultural assets identified in the municipalities of Parelhas and Carnaúba dos Dantas - RN . The activities carried out in the ADA, AID and Alll, and the cataloging of inventoried assets of the communities around the Adutora allowed to register, together with IPHAN, 56 archaeological sites as well as the 9 properties built in the areas affected by the pipeline.

Keywords: Cultural Heritage, Archaeological Sites, Rio Grande do Norte 


\section{Introdução}

O presente relatório contém as atividades referentes à elaboração do Inventário de Referências Culturais da área de abrangência do Sistema Adutor Seridó - Trecho Parelhas / Carnaúba dos Dantas - RN.

O monitoramento arqueológico da área de abrangência da Adutora tem por objetivo atender à legislação e às normas vigentes que regulamentam a realização de obras impactantes em áreas com patrimônio arqueológico (da Instrução Normativa no. 001 de 25 de março de 2015, Portaria 230/02 do Iphan e Resolução Conama 001/86).

As atividades de arqueologia aqui apresentadas têm como objetivo o fornecimento de informações necessárias à realização do levantamento cartográfico, posicionamento de sítios/ocorrências arqueológicas e cadastramento de bens culturais existentes na região de intervenção da obra do Sistema Adutor Seridó - Trecho Parelhas - Carnaúba dos Dantas.

No plano arqueológico, a área de abrangência da Adutora concentra um grande potencial em informações pré-históricas e históricas, sobretudo no que se refere a sítios pré-históricos portadores de registros rupestres.

\section{Inventário de Referências Culturais no Distrito de Cobra, Parelhas - RN}

A Adutora Seridó começou a ser construída em 2010. Naquele primeiro momento foram executados 3,5 km, a partir do município de Carnaúba dos Dantas até o Reservatório Apoiado. Ato contínuo, no período de novembro de 2012 até setembro de 2013, foi dado seguimento à obra, executando mais de $20 \mathrm{~km}$, desde o Reservatório Apoiado até a Estação de Tratamento de Água (ETA) localizado no município de Parelhas. Em seguida, no período de setembro de 2015 a janeiro de 2016, as obras foram concluídas, tendo sido executado o trecho desde a ETA até o ponto de captação de água no Açude Boqueirão, somando cerca de $500 \mathrm{~m}$ em tal etapa.

A fim de facilitar a manutenção do sistema após a sua implantação, o Projeto da Adutora Seridó previu a sua construção ao lado de estradas não pavimentadas. 0 trabalho também previu a instalação de duas Sub-adutoras, uma vez que o traçado previsto passava pelos povoados de Joazeiro e Santo Antônio (Cobra), no município de Parelhas.

Em Parelhas, foram identificadas 3 comunidades distritais na área de abrangência da Adutora, quais sejam: Santo Antônio de Cobra, Joazeiro e Boa Vista dos Negros.

Desde que a Constituição brasileira de 1988 adotou a visão antropológica de cultura, caracterizada como uma dinâmica social e de referências culturais, fez-se urgente a identificação e registro dos bens culturais existentes no país. Isso porque a crescente modernização da sociedade e os grandes projetos de investimentos que foram gerados em consonância com ela motivou, na maioria das vezes, desequilíbrios sociais e o desaparecimento e/ou ressignificação de bens socioculturais de natureza diversificada. Diante do exposto, é imprescindível que estudos de impactos socioculturais sejam conduzidos, a fim 
de quantificar e qualificar os efeitos de grandes projetos em determinada localidade do território brasileiro.

Do mito de fundação do povoado das "terras da Cobra", passando pela religiosidade ligada ao Alto dos Meninos no Joazeiro, até a produção chouriço na comunidade quilombola da Boa Vista dos Negros e a musicalidade presente nos municípios de Carnaúba dos Dantas e Parelhas, pode ser observado o potencial do Patrimônio material e imaterial da região.

A Tabela 1 apresenta o quantitativo do patrimônio arqueológico, material edificado e imaterial identificados nas comunidades que circundam a Adutora e seu entorno.

Tabela 1: Quantificação do Patrimônio Arqueológico, Material e Imaterial das comunidades posicionadas na abrangência da Adutora. Fonte: C\&M Arqueologia, 2016.

\begin{tabular}{|c|c|c|c|c|c|c|c|c|c|}
\hline \multirow{2}{*}{ MUNICÍPIO } & \multirow{2}{*}{ COMUNIDADE } & \multicolumn{2}{|c|}{$\begin{array}{l}\text { PATRIMÔNIO } \\
\text { ARQUEOLÓGICO }\end{array}$} & \multicolumn{4}{|c|}{ PATRIMÔNIO IMATERIAL } & \multicolumn{2}{|c|}{$\begin{array}{l}\text { PATRIMÔNIO } \\
\text { EDIFICADO }\end{array}$} \\
\hline & & Sítios & Ocorrências & Danças & Culinária & $\begin{array}{l}\text { Saberes e } \\
\text { Fazeres }\end{array}$ & Celebrações & Edifícios & Local \\
\hline \multirow{3}{*}{ Parelhas } & Limite municipal & 5 & 6 & $\begin{array}{l}\text { Orques } \\
\text { tra } \\
\text { sinfônic } \\
\text { a de } \\
\text { Parelha } \\
\mathrm{s} \text {; } \\
\text { Banda } \\
\text { de } \\
\text { música } \\
11 \text { de } \\
\text { fevereir } \\
\text { o } \\
\end{array}$ & & & $\begin{array}{l}\text { São } \\
\text { Sebastião }\end{array}$ & $\begin{array}{l}\text { Igreja } \\
\text { Matriz de } \\
\text { São } \\
\text { Sebastião } \\
\text {; Casa da } \\
\text { Cultura }\end{array}$ & $\begin{array}{l}\text { Barragem } \\
\text { do } \\
\text { Boqueirão } \\
\text { de } \\
\text { Parelhas; } \\
\text { Sítio } \\
\text { arqueológ } \\
\text { ico } \\
\text { Mirador } \\
\text { de } \\
\text { Parelhas }\end{array}$ \\
\hline & $\begin{array}{l}\text { Santo Antônio } \\
\text { "Cobra" }\end{array}$ & 1 & & & & $\begin{array}{l}\text { Dona Luzia } \\
\text { Rezadeira; }\end{array}$ & $\begin{array}{l}\text { Santo } \\
\text { Antônio; } \\
\text { Santa Luzia; } \\
\text { Carnaval }\end{array}$ & $\begin{array}{l}\text { Capela de } \\
\text { Santo } \\
\text { Antônio }\end{array}$ & $\begin{array}{l}\text { Museu do } \\
\text { povoado } \\
\text { de Cobra }\end{array}$ \\
\hline & Joazeiro & & & & & $\begin{array}{l}\text { Vassouras; } \\
\text { Pinturas } \\
\text { em telha; } \\
\text { Poesia e } \\
\text { cantoria } \\
\text { de S. } \\
\text { Neco; } \\
\text { Reza de D. } \\
\text { Nazaré; } \\
\text { Brinquedo } \\
\text { s e } \\
\text { utensílios } \\
\text { de } \\
\text { madeira } \\
\text { de Zé de } \\
\text { Paulo }\end{array}$ & $\begin{array}{l}\text { Virgem dos } \\
\text { Pobres; } \\
\text { Nossa } \\
\text { Senhora do } \\
\text { Ó }\end{array}$ & $\begin{array}{l}\text { Capela } \\
\text { Nossa } \\
\text { Senhora } \\
\text { Virgem } \\
\text { dos } \\
\text { Pobres; } \\
\text { Capela } \\
\text { Nossa } \\
\text { Senhora } \\
\text { do Ó; } \\
\text { Covinha }\end{array}$ & $\begin{array}{l}\text { Alto dos } \\
\text { Meninos; } \\
\text { Cemitério } \\
\text { do Cólera }\end{array}$ \\
\hline Parelhas & $\begin{array}{l}\text { Boa Vista dos } \\
\text { Negros }\end{array}$ & & & $\begin{array}{l}\text { Espont } \\
\text { ão }\end{array}$ & Chouriço & & $\begin{array}{l}\text { Nossa } \\
\text { Senhora do } \\
\text { Rosário }\end{array}$ & $\begin{array}{l}\text { Capela de } \\
\text { Nossa } \\
\text { Senhora } \\
\text { do } \\
\text { Rosário }\end{array}$ & \\
\hline $\begin{array}{l}\text { Carnaúba } \\
\text { dos Dantas }\end{array}$ & Limite municipal & 50 & 3 & $\begin{array}{l}\text { Filarmô } \\
\text { nica } 11 \\
\text { de } \\
\text { Dezem } \\
\text { bro }\end{array}$ & & $\begin{array}{l}\text { Dona Dadi } \\
\text { calungueir } \\
\text { a }\end{array}$ & $\begin{array}{l}\text { Santa Luzia; } \\
\text { Nossa } \\
\text { Senhora das } \\
\text { Vitórias }\end{array}$ & $\begin{array}{l}\text { Igreja } \\
\text { Matriz de } \\
\text { São José, } \\
\text { Grupo } \\
\text { Escolar } \\
\text { Caetano } \\
\text { Dantas }\end{array}$ & $\begin{array}{l}\text { Monte do } \\
\text { Galo; } \\
\text { Museu } \\
\text { Histórico } \\
\text { Nossa } \\
\text { Senhora } \\
\text { das } \\
\text { Vitórias }\end{array}$ \\
\hline
\end{tabular}


Município de Parelhas

O município de Parelhas localiza-se na região do Seridó, tem cerca de 20.300 habitantes. A sua fundação data de 1856. Os primeiros habitantes vieram da Paraíba no final do regime das sesmarias, eram eles Félix Gomes Pereira, Sebastião Gomes de Oliveira e Cosme Luiz. Eles tinham a missão de fixar residência e povoar o local (Santos, 2007).

Naquela época, Parelhas era lugar de passagem e descanso para os tropeiros que faziam o caminho da Paraíba para o município de Caicó. Os mesmos utilizavam a cidade para descanso. Essa atividade acabou desenvolvendo o povoado de Parelhas, que pertencia à cidade de Jardim do Seridó (Santos, 2007).

Até a década de 1960 a economia da cidade era predominantemente de agricultura rural. Hoje, a produção de cerâmica é a maior da região sendo a grande responsável pelos empregos gerados.

Tabela 2: Sítios e Ocorrências Arqueológicas identificadas no decorrer das atividades de prospecção de superfície na ADA, AID e All no município de Parelhas - RN. Fonte: C\&M Arqueologia, 2016.

\begin{tabular}{|l|l|c|c|c|}
\hline \multicolumn{1}{|c|}{ Nome } & Município & Altimetria & Localização & Categoria \\
\hline Casa Velha & Parelhas & 344 & ADA & Ocorrência \\
\hline Fazenda do Chicola & Parelhas & 325 & ADA & Ocorrência \\
\hline Serrotinho do Joazeiro & Parelhas & 326 & ADA & Ocorrência \\
\hline Fogueira do Abrigo & Parelhas & 318 & AID & Ocorrência \\
\hline Garrafa Branca & Parelhas & 330 & AID & Ocorrência \\
\hline Olaria do Salgadinho & Parelhas & 305 & AID & Ocorrência \\
\hline Boqueirão de Parelhas & Parelhas & 319 & AID & Sítio \\
\hline Mirador de Parelhas & Parelhas & 370 & All & Sítio \\
\hline Pedra do Chinelo & Parelhas & 350 & All & Sítio \\
\hline Pedra do Vem-Vem & Parelhas & 383 & All & Sítio \\
\hline $\begin{array}{l}\text { Toca do Olho D'agua } \\
\text { das Gatas }\end{array}$ & Parelhas & 383 & All & All \\
\hline Sol e Lua & Parelhas & 340 & & \\
\hline
\end{tabular}

No município de Parelhas foram identificados 6 (seis) Sítios Arqueológicos e 6 (seis) Ocorrências Arqueológicas, conforme Tabela 2, os quais estão citados no presente relatório no decorrer das atividades de prospecção na Área Diretamente Afetada - $\mathrm{ADA}^{1}$, Área de Influência Direta - AID $^{2}$ e Área de Influência Indireta - AlI $^{3}$ da Adutora. Do universo de sítios referidos, apenas 4 (quatro) estão cadastrados no Iphan.

\footnotetext{
${ }^{1}$ A Área Diretamente Afetada - ADA é aquela que sofre diretamente as intervenções de implantação e operação da atividade. No caso específico da Adutora Seridó, utilizou-se como critério definidor da ADA uma área de $6 \mathrm{~m}$ de largura tendo como ponto central a tubulação da Adutora, logo 3 m para cada lado (Instrução Normativa no. 125/2006 do IBAMA).

2 Área de Influência Direta (AID) é a área que está sujeita aos impactos diretos da implantação e operação do empreendimento. No caso da Adutora Seridó a AID foi delimitada tendo como base uma faixa de $400 \mathrm{~m}$ ao longo do traçado da Adutora, sendo 200
} 
Relatório das Referências Culturais e Arqueológicas da Área de Abrangência do Sistema Adutor Seridó - Trecho Parelhas / Carnaúba dos Dantas RN- Brasil

\section{Povoado de Santo Antônio (Cobra)}

O povoado de Santo Antônio faz parte da zona rural do município de Parelhas - RN e localiza-se a $18 \mathrm{~km}$ da sede municipal. Estima-se que a população seja de 1.000 pessoas, distribuídas em uma área de $36 \mathrm{Km}^{2}$ (Santos, 2007).

Constitui-se de um conglomerado de casas e ruas que tem como referência uma avenida única, a Tertuliano Rodrigues da Silva. O local dispõe de escola de ensino fundamental, creche, posto de saúde, centro social, praças, quadra de esportes, clube de terceira idade e capela (Figura 01).

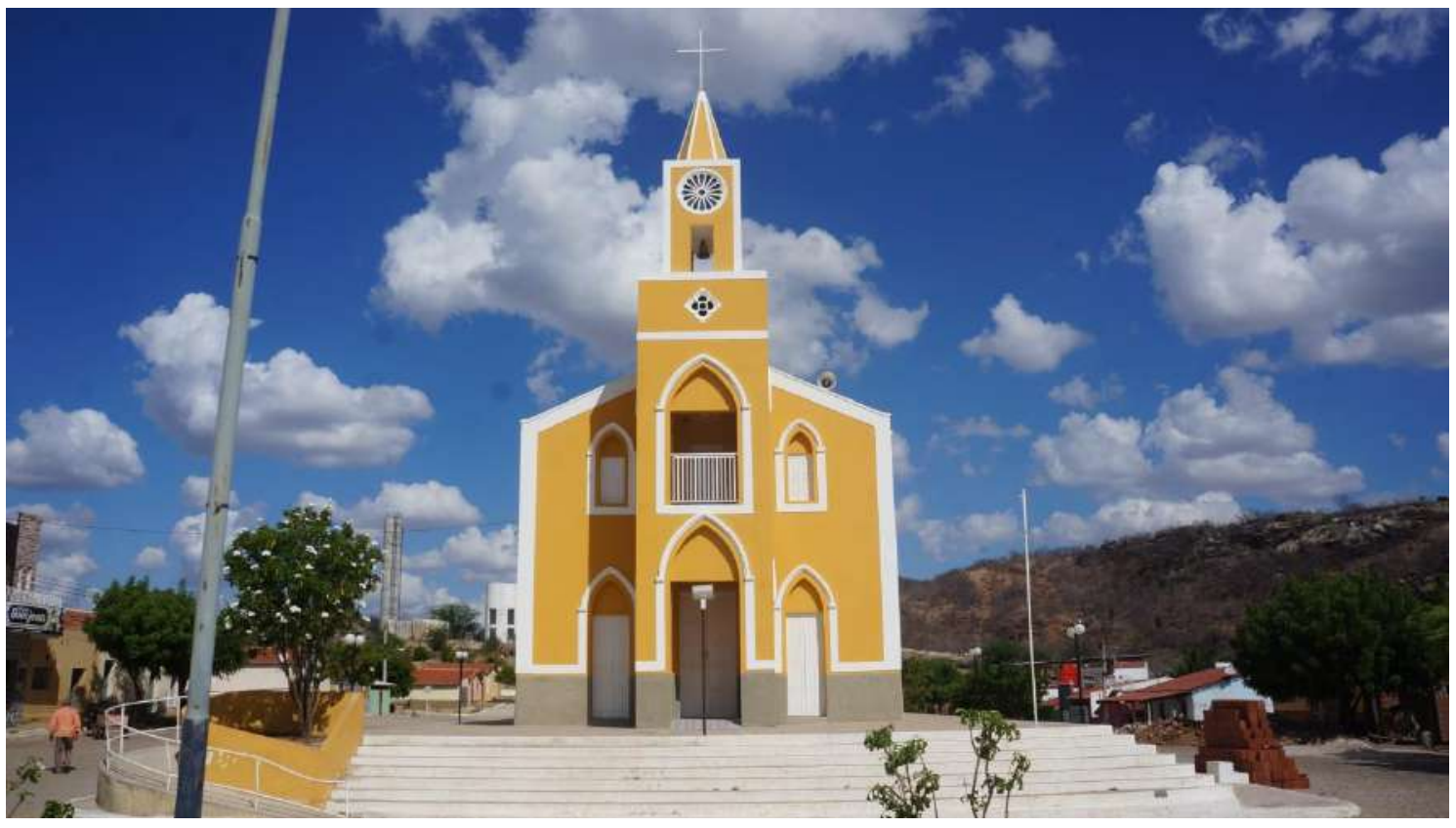

Figura 01: Capela de Santo Antônio. Povoado Santo Antônio, Parelhas - RN. Fonte: C\&M Arqueologia, 2016.

A economia da região gira em torno da produção de telhas e tijolos e das cooperativas de costura, ambas as atividades representando boa parte das oportunidades de emprego para os moradores da comunidade.

No que tange ao contexto arqueológico, foi identificado na localidade, durante as atividades de prospecção da Área de Influência Indireta - All da Adutora, um sítio Pré-Histórico com registros rupestres denominado Sol e Lua.

m para cada lado da tubulação, haja vista que nesta área a implantação e a operação do empreendimento provocou impactos diretos (Instrução Normativa no. 125/2006 do IBAMA).

\footnotetext{
3 Área de Influência Indireta (All) é a área real ou potencialmente ameaçada pelos impactos indiretos da implantação e operação da atividade. No que concerne a Adutora Seridó, a delimitação da All caracteriza-se pela totalidade dos municípios que integram a área da Adutora, quais sejam Carnaúba dos Dantas e Parelhas - RN (Instrução Normativa no. 125/2006 do IBAMA).
} 


\section{Povoado de Joazeiro}

O Povoado de Joazeiro pertence ao município de Parelhas - RN, distando $13 \mathrm{~km}$ da sede municipal. Não foram identificados dados sobre quantitativos populacionais daquela região.

É um povoado de pequeno porte que se desenvolveu ao redor da Capela de Nossa Senhora Virgem dos Pobres (Figura 02). Atualmente conta com posto de saúde, creche, escola, campo de futebol e praças. Recebeu pavimentação recentemente através de uma parceria realizada entre a Prefeitura de Parelhas e a Cerâmica Tavares, empresa responsável pelo maior número de empregos da região.

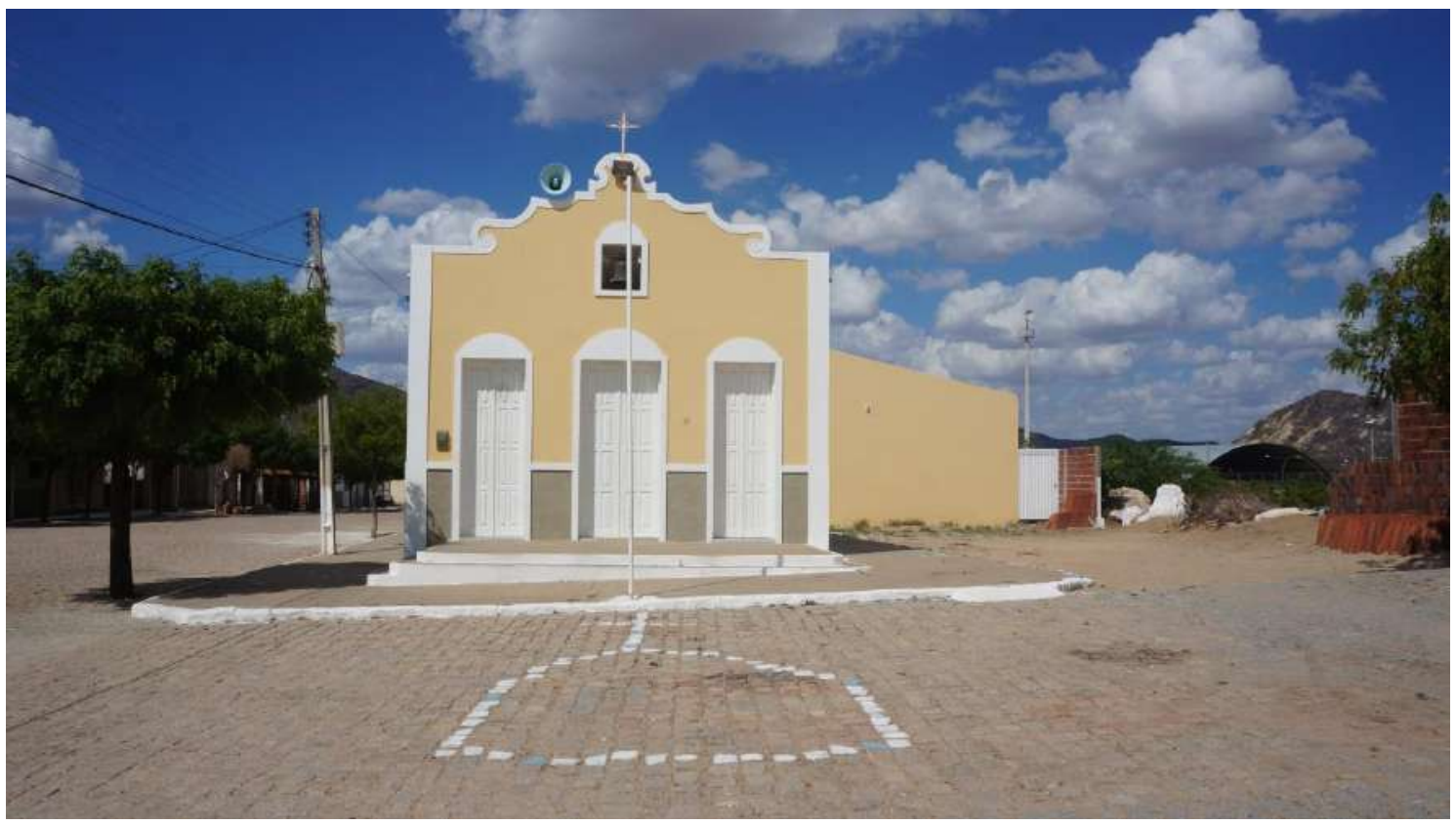

Figura 02: Capela de Nossa Senhora Virgem dos Pobres. Povoado Joazeiro, Parelhas - RN. Fonte: C\&M Arqueologia, 2016.

A economia da região gira em torno da Cerâmica Tavares e de uma Cooperativa de Costura presente nos arredores do povoado. No entorno deste distrito foi identificada 1 (uma) ocorrência arqueológica, denominada Serrotinho do Joazeiro, caracterizada, sobretudo, por vestígios cerâmicos.

\section{Comunidade de Boa Vista dos Negros}

A Comunidade de Boa Vista dos Negros pertence ao município de Parelhas - RN, distando $7 \mathrm{~km}$ da sede municipal. Estima-se que a população seja de 100 habitantes.

Existem várias versões que tentam explicar o surgimento do povoado de Boa Vista. Optou-se aqui por dar voz ao Sr. Manuel Miguel, um dos moradores mais antigos da comunidade. Ele contou que o povoamento da cidade se deu da seguinte maneira:

Eram três negras aí uma ficou aqui, ali no Maracujá. Um sítio que tinha ali. E a outra ficou no Olho D’água, ali na frente. E a outra ficou em Jardim (do Seridó). Aí foi... Essa negra que ficou aqui ela foi pra casa de um cara que se 
chamava Coronel Gurjão. Bicho rico da moléstia! No tempo... Era Tereza o nome dela. Um dia Tereza apareceu grávida. Era solteira, né? Apareceu grávida. Aí lá vai, lá vai. Aí o coronel, era o coronel Gurjão. Aí o coronel foi e disse: “- Não. Essa mulher não pode ficar aqui". Aí foi e doou esse terreno aqui pra ela. Pra ela e o filho dela. Doou. Aí Tereza ficou aqui (...). Ela teve o filho. O filho dela chamava Domingos. Aí de Domingos nasceu Antônio Lutero. De Antônio Lutero nasceu Roberto que é meu bisavô. Aí nasceu meu avô. Aí ficamos aqui.

A história contada pelo Sr. Manuel Miguel é repetida por outros moradores com algumas variações. Estima-se que Tereza teria chegado a tais terras no período da grande seca de 179193 (Cavignac, 2007). Naquela localidade Tereza teria fixado residência dando origem ao povoado que passou a ser conhecido como Boa Vista dos Negros.

O Sr. Manuel Miguel explica ainda a ligação do seu povo com a irmandade de Nossa Senhora do Rosário, atuante na região do Seridó desde o século XVIII. Conta que foi encontrada por aquelas terras uma imagem de Nossa Senhora do Rosário, a qual foi levada para a cidade de Jardim do Seridó. Por três vezes a imagem foi carregada e três vezes ela voltou a aparecer no mesmo local. Apenas quando os negros se reuniram e levaram a imagem se expressando por meio da dança do Espontão é que foi construída uma capela (Figura 03) em homenagem a santa em Boa Vista dos Negros. De lá ela não mais saiu.

Diante disso, percebe-se que os pilares da comunidade criada pelos filhos de Tereza sempre foram a identidade negra, reforçada por meio da dança do Espontão, e a religião ligada à irmandade de Nossa Senhora do Rosário.

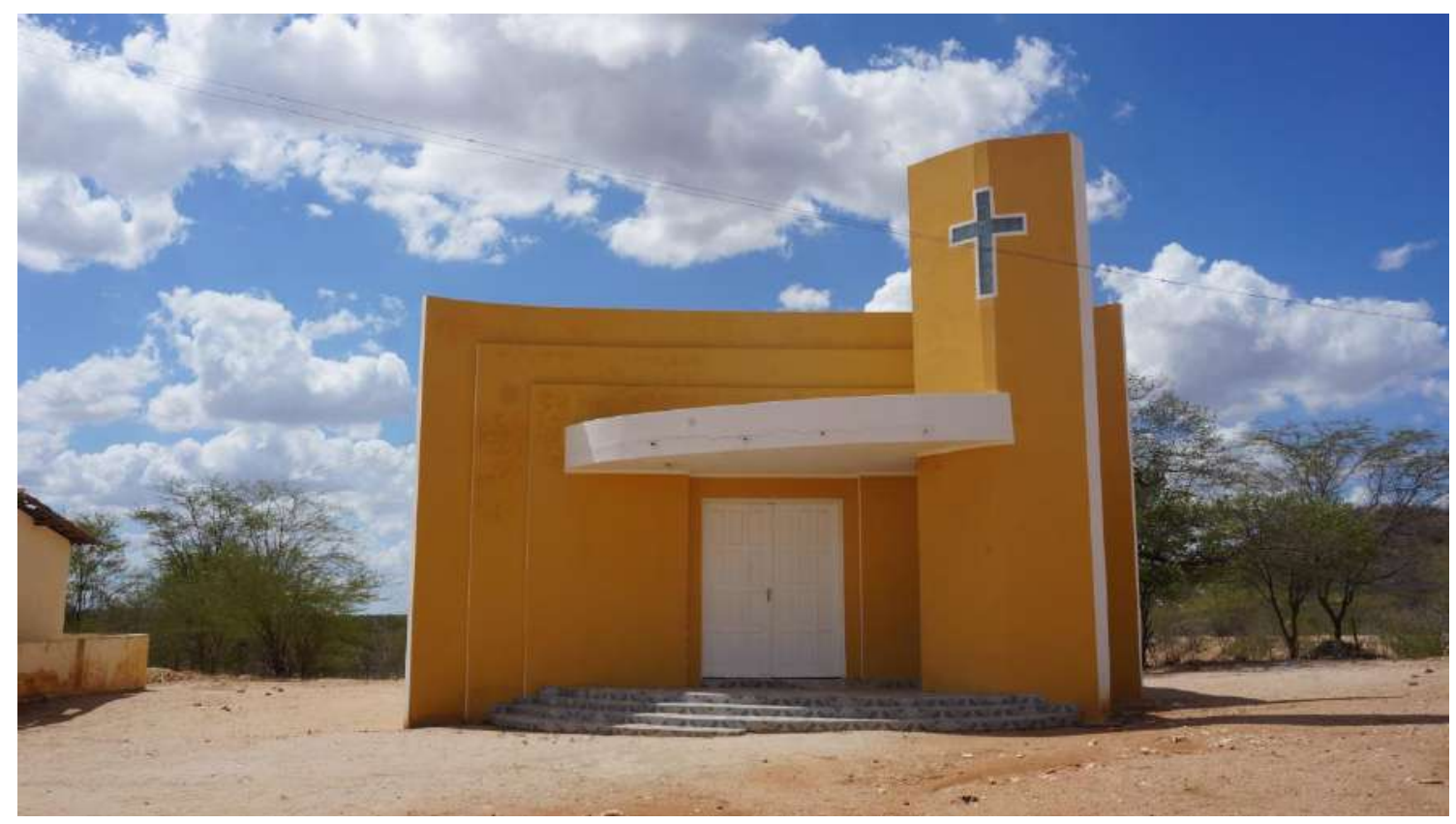

Figura 03: Capela Nossa Senhora do Rosário. Povoado da Boa Vista dos Negros, Parelhas - RN. Fonte: C\&M Arqueologia, 2016. 
Atualmente, a comunidade possui uma escola, posto de saúde, quadra poliesportiva, campo de futebol e capela dedicada à Nossa Senhora do Rosário. A escola foi desativada há alguns anos por falta de alunos. As crianças e jovens em idade escolar deslocam-se para o povoado vizinho de Joazeiro ou para a cidade de Parelhas. No entorno da comunidade não foram identificados vestígios arqueológicos.

\section{Município de Carnaúba dos Dantas}

Está localizado na região do Seridó e possui 4.420 habitantes. A cidade deve seu nome à planta cultivada nas antigas fazendas da região, que eram de propriedade da família Dantas. 0 primeiro morador da localidade teria sido Caetano Dantas Correia. A região seria emancipada à categoria de cidade somente em 1953. O território é composto por sede e dois povoados: Ermo e Rajada. O principal curso de água que corta a região é o do rio Carnaúba, que nasce na Serra do Abreu e deságua no Rio Acauã (Santos, 2007).

Hoje, em Carnaúba dos Dantas encontram-se pousadas, restaurantes, escolas, bancos, praças, prefeitura, secretaria, hospitais, horto, entre outros. A principal igreja da cidade é a Matriz de São José (Figura 04), localizada no Centro, mas também de igual importância para a religiosidade do local o Santuário de Santa Rita de Cássia, localizado no Monte do Galo.

A principal atividade econômica da região é a produção de cerâmica vermelha, sobretudo telhas. A produção abastece todo o estado do Rio Grande do Norte e gera emprego e renda para os moradores da cidade.

No município de Carnaúba dos Dantas foram identificados conforme Tabela 3, 50 (Cinquenta) Sítios e 3 (três) Ocorrências Arqueológicas, tendo como vestígios arqueológicos predominantes os registros rupestres. Do universo de sítios referidos, estão cadastrados no Iphan, 26 (vinte e seis).

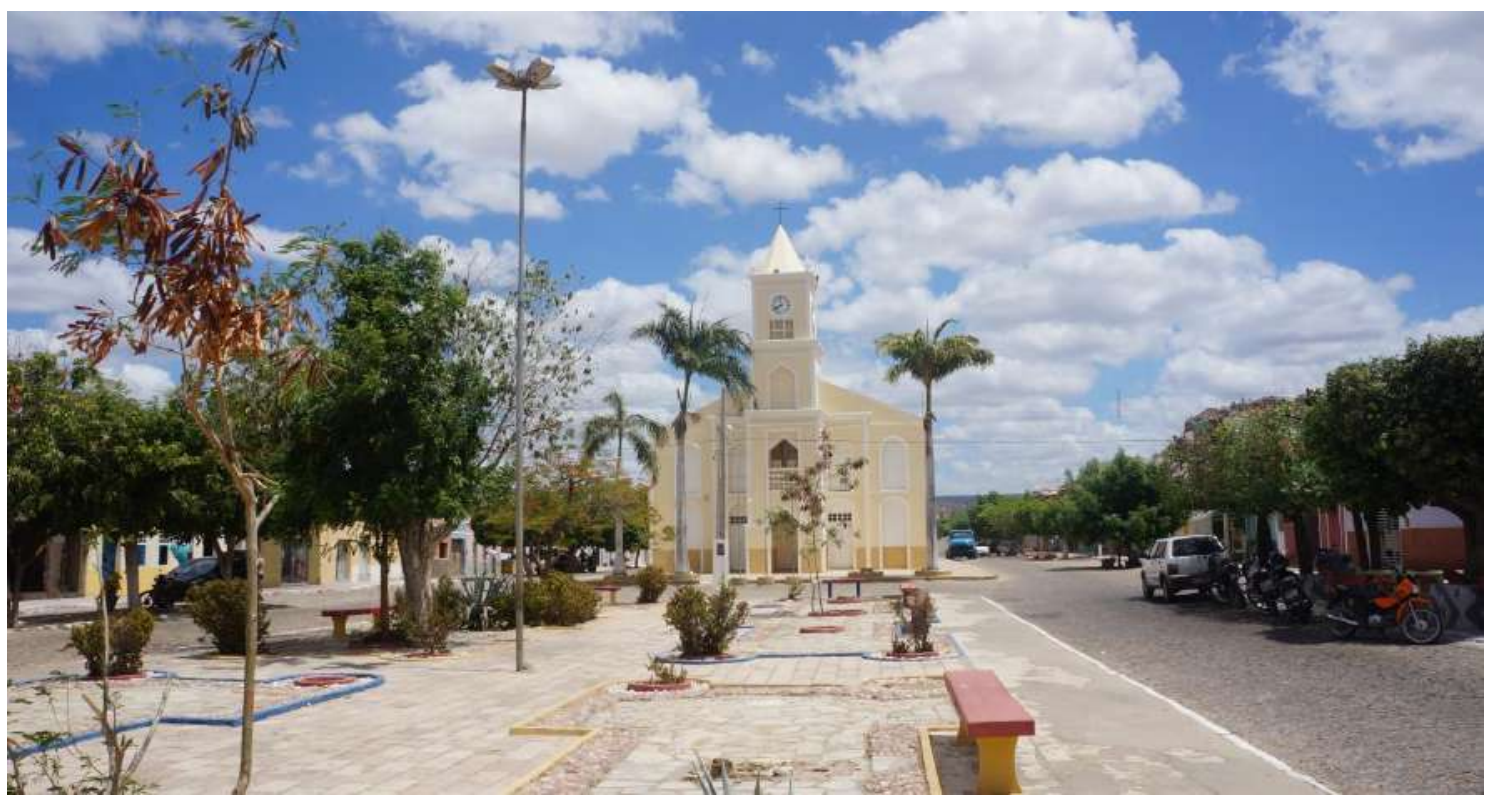

Figura 04: Igreja Matriz de São José. Carnaúba dos Dantas - RN. Fonte: C\&M Arqueologia, 2016. 
Tabela 3: Sítios e Ocorrências Arqueológicas identificadas no decorrer das atividades de prospecção de superfície na AID e All no município de Carnaúba dos Dantas - RN. Fonte: C\&M Arqueologia, 2016.

\begin{tabular}{|c|c|c|c|c|}
\hline Nome & Município & Altimetria & Localização & Categoria \\
\hline Córrego do Cata-vento & Carnaúba dos Dantas & 342 & ADA & Ocorrência \\
\hline Zezinho do Cobra & Carnaúba dos Dantas & 350 & ADA & Ocorrência \\
\hline Campo de Futebol & Carnaúba dos Dantas & 354 & AID & Ocorrência \\
\hline Matacão do Dean & Carnaúba dos Dantas & 371 & AID & Sítio \\
\hline Serrote das Areias & Carnaúba dos Dantas & 399 & AID & Sítio \\
\hline Abrigo do Morcego & Carnaúba dos Dantas & 380 & All & Sítio \\
\hline Baixa do Umbuzeiro & Carnaúba dos Dantas & 369 & All & Sítio \\
\hline Cachoeira das Canoas I & Carnaúba dos Dantas & 460 & All & Sítio \\
\hline Cachoeira do Brás & Carnaúba dos Dantas & 435 & All & Sítio \\
\hline Cachoeira do Letreiro & Carnaúba dos Dantas & 452 & All & Sítio \\
\hline Cachoeira dos Tanquinhos & Carnaúba dos Dantas & 355 & All & Sítio \\
\hline Casa de Pedra & Carnaúba dos Dantas & 534 & All & Sítio \\
\hline Casa Santa & Carnaúba dos Dantas & 536 & All & Sítio \\
\hline Chã do Caboclo & Carnaúba dos Dantas & 572 & All & Sítio \\
\hline Deca & Carnaúba dos Dantas & 529 & All & Sítio \\
\hline Escondido da Rajada & Carnaúba dos Dantas & 312 & All & Sítio \\
\hline Fundões I & Carnaúba dos Dantas & 391 & All & Sítio \\
\hline Fundões II & Carnaúba dos Dantas & 361 & All & Sítio \\
\hline Fundões III & Carnaúba dos Dantas & 410 & All & Sítio \\
\hline Furna da Desilusão & Carnaúba dos Dantas & 375 & All & Sítio \\
\hline Furna do Borrachinha & Carnaúba dos Dantas & 370 & All & Sítio \\
\hline Furna do Mateus & Carnaúba dos Dantas & 388 & All & Sítio \\
\hline Furna do Messias & Carnaúba dos Dantas & 560 & All & Sítio \\
\hline Furna do Pau D'Arco & Carnaúba dos Dantas & 430 & All & Sítio \\
\hline Furna do Umbuzeiro & Carnaúba dos Dantas & 388 & All & Sítio \\
\hline Furna dos Caboclos & Carnaúba dos Dantas & 568 & All & Sítio \\
\hline Lajedo & Carnaúba dos Dantas & 366 & All & Sítio \\
\hline Mão Redonda & Carnaúba dos Dantas & 355 & All & Sítio \\
\hline Maribondo II & Carnaúba dos Dantas & 320 & All & Sítio \\
\hline Pedra da Canoa I & Carnaúba dos Dantas & 488 & All & Sítio \\
\hline Pedra da Macambira & Carnaúba dos Dantas & 402 & All & Sítio \\
\hline Pedra da Mesa & Carnaúba dos Dantas & 419 & All & Sítio \\
\hline Pedra da Unha & Carnaúba dos Dantas & 398 & All & Sítio \\
\hline Pedra do Alexandre & Carnaúba dos Dantas & 410 & All & Sítio \\
\hline Pedra do Cavalo & Carnaúba dos Dantas & 405 & All & Sítio \\
\hline Pedra do Reino & Carnaúba dos Dantas & 427 & All & Sítio \\
\hline Pinhão Branco & Carnaúba dos Dantas & 418 & All & Sítio \\
\hline Poço do Caramuru & Carnaúba dos Dantas & 397 & All & Sítio \\
\hline Potes & Carnaúba dos Dantas & 412 & All & Sítio \\
\hline Sítio do Galo & Carnaúba dos Dantas & 320 & All & Sítio \\
\hline Talhado do Gavião & Carnaúba dos Dantas & 455 & All & Sítio \\
\hline Talhado da Onça & Carnaúba dos Dantas & 535 & All & Sítio \\
\hline Talhado das Pirogas & Carnaúba dos Dantas & 356 & All & Sítio \\
\hline Talhado do Menalcas & Carnaúba dos Dantas & 393 & All & Sítio \\
\hline Talhado do Urubu & Carnaúba dos Dantas & 495 & All & Sítio \\
\hline Talhado dos Cabeços & Carnaúba dos Dantas & 544 & All & Sítio \\
\hline Xique-Xique I & Carnaúba dos Dantas & 427 & All & Sítio \\
\hline Xique-Xique II & Carnaúba dos Dantas & 402 & All & Sítio \\
\hline Xique-Xique III & Carnaúba dos Dantas & 415 & All & Sítio \\
\hline Xique-Xique VI & Carnaúba dos Dantas & 406 & All & Sítio \\
\hline Serrote do Zé do Bode & Carnaúba dos Dantas & 358 & All & Sítio \\
\hline Furna do João & Carnaúba dos Dantas & 407 & All & Sítio \\
\hline
\end{tabular}




\section{Sítios e Ocorrências Arqueológicas Identificadas na ADA, AID e All}

Durante as atividades de prospecção de superfície na Área Diretamente Afetada (ADA) foram identificadas 5 (cinco) Ocorrências Arqueológicas caracterizadas por presença majoritária de vestígios cerâmicos, com diferentes técnicas de manufatura, antiplástico e tratamento de superfície (Mapa 1). As Ocorrências Fazenda do Chicola, Serrotinho do Joazeiro e Casa Velha localizadas no município de Parelhas; Córrego do Cata-vento e Zezinho do Cobra, localizadas no município de Carnaúba dos Dantas. Todas as evidências arqueológicas foram georreferenciadas com auxílio de GPS - modelo Garmin GPSmap 60CSx e registradas por meio de fotografias e croquis.

As ocorrências foram cadastradas mediante os descritores do protocolo criado para o projeto (incluindo georreferenciamento, fotografias e croquis). Não houve, no entanto, intervenção na subsuperfície ou coleta de vestígios. Esses permaneceram em seus locais de origem devido à ausência de autorização do Iphan para tal procedimento.

Com vistas a verificar eventuais impactos ao Patrimônio Arqueológico na Área de Influência Direta (AID), foram realizadas prospecções de superfície em uma faixa de $400 \mathrm{~m}$ ao longo do traçado, sendo $200 \mathrm{~m}$ para cada lado da tubulação.

O procedimento metodológico adotado para prospecção na AID foi o de Prospecção Amostral Estratificada, caracterizado pela inspeção de áreas com maior probabilidade de identificar vestígios arqueológicos (Domingo, Burke e Smith, 2007).

Durante a prospeç̧ão foram identificados 4 (quatro) ocorrências arqueológicas caracterizadas pela presença cerâmicas, grés e estrutura de combustão. As Ocorrências Fogueira do Abrigo, Garrafa Branca e Olaria do Salgadinho, localizam-se no município de Parelhas; e a Ocorrência Campo de Futebol, localizada no município de Carnaúba dos Dantas.

$\mathrm{Na}$ AID foram identificados 3 (três) Sítios Arqueológicos (Mapa 2) caracterizados pela presença de registros rupestres, são eles: Boqueirão de Parelhas, no município de Parelhas e Serrote das Areias e Matacão do Dean no município de Carnaúba dos Dantas. 


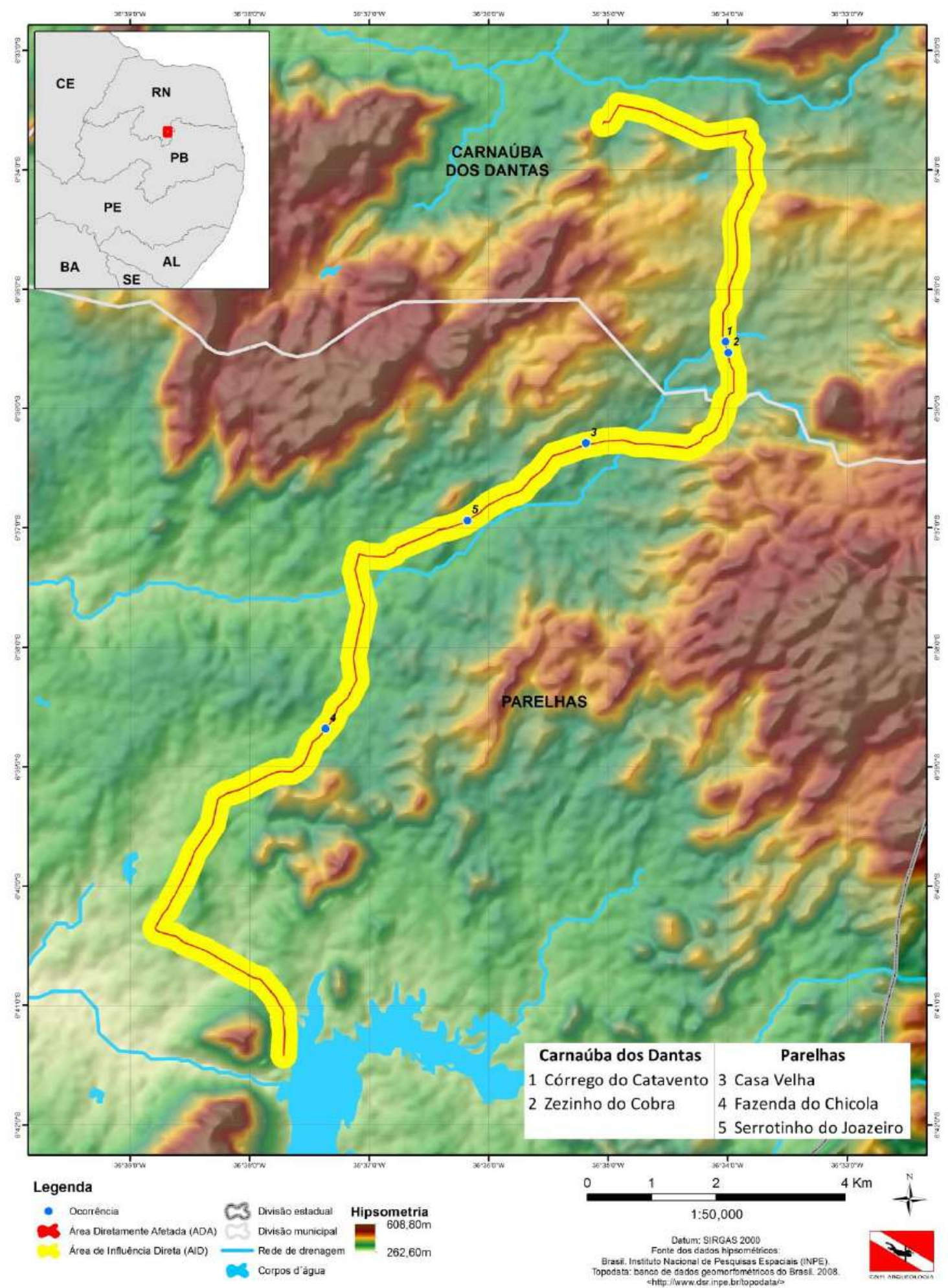

Mapa 1: Mapa com a localização das ocorrências arqueológicas identificadas ao longo do Traçado do Sistema Adutor Seridó - Trecho Parelhas - Carnaúba dos Dantas, durante a realização da prospecção superficial sistemática da ADA. Fonte: C\&M Arqueologia, 2016. 


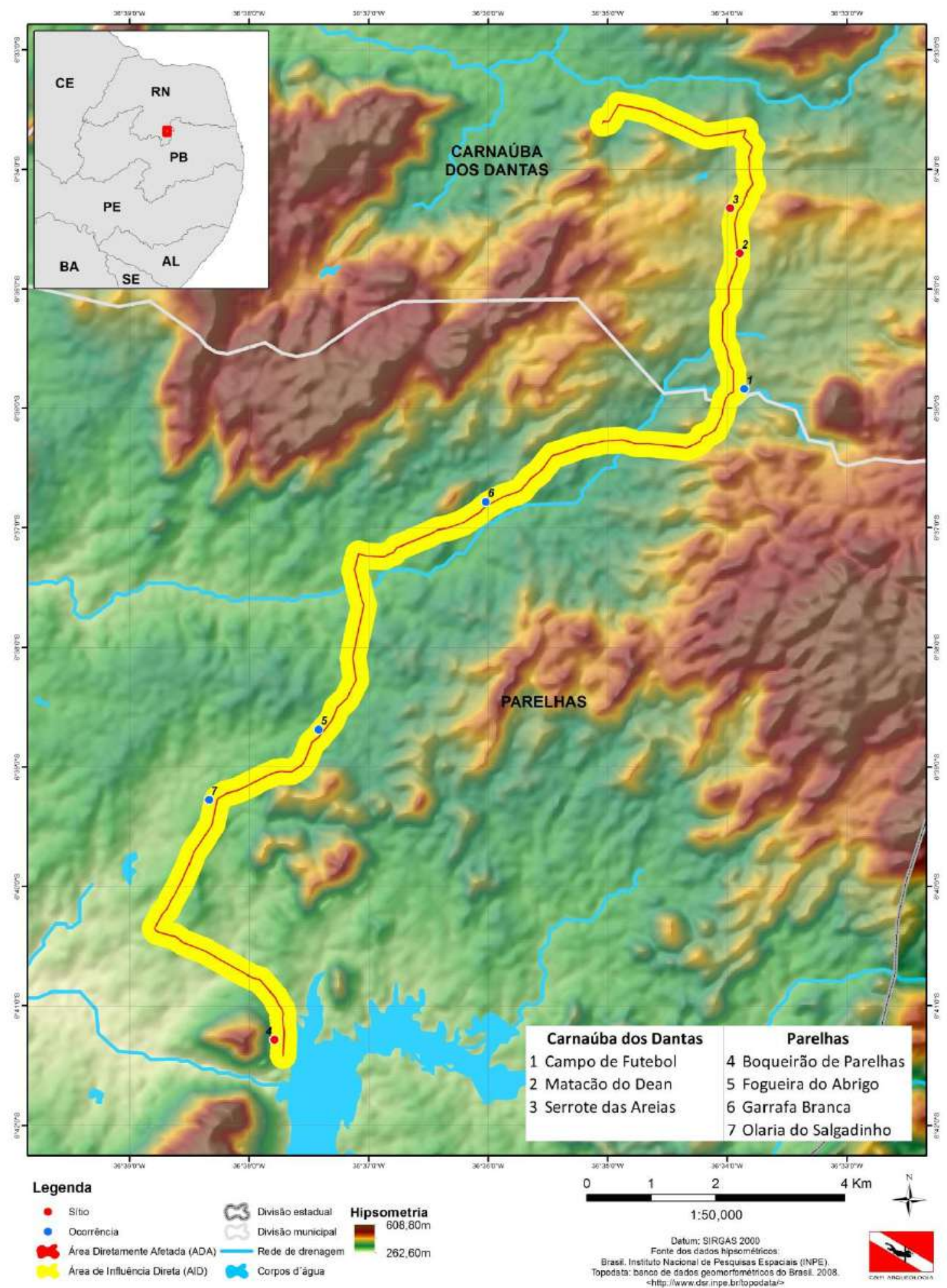

Mapa 2: Localização das 'Ocorrências' e 'Sítio Arqueológico' identificados ao longo do Traçado do Sistema Adutor Seridó - Trecho Parelhas - Carnaúba dos Dantas durante a realização da prospecção superficial sistemática da AID. Observa-se no mapa acima a localização das ocorrências e sítios. Fonte: C\&M Arqueologia, 2016. 
Com objetivo de verificar eventuais impactos ao patrimônio arqueológico na Área de Influência Indireta (All) foram realizadas prospecções de superfície nos municípios de Parelhas-RN e Carnaúba dos Dantas-RN, na área cuja implantação e operação do empreendimento possa ter provocado impactos indiretos.

O procedimento metodológico adotado para prospecção da All foi o de Prospecção Amostral Estratificada. Nessas áreas foram realizadas prospecções superficiais sistemáticas para o reconhecimento do terreno, que consiste na inspeção direta e exaustiva da superfície, sem realizar intervenções e coleta de materiais. As áreas selecionadas foram escolhidas com base nas suas características geográficas (Domingo, Burke e Smith, 2007).

O registro dos sítios arqueológicos foi realizado considerando as classes de sítio, e aplicado, de acordo com suas especificações.

Para sítios a céu aberto, observou-se a maior concentração de vestígios em superfície e partir desta, estabelecido um raio de dispersão para a sua delimitação.

Para sítio em abrigo sob-rocha, observou-se suas dimensões e a orientação da abertura do abrigo. Para registro das pinturas, a fim de tornar mais didático e aperfeiçoar a análise, foi necessário estabelecer limites para as concentrações. Estes seguiram divisões naturais, da própria formação rochosa, e quando inexistente, seccionou-se pelo distanciamento mínimo entre as concentrações de figuras de $50 \mathrm{~cm}$.

$\mathrm{Na}$ All foram identificados 53 (cinquenta e três) Sítios Arqueológicos caracterizados pela presença de registros rupestres, vestígios cerâmicos, líticos e estruturas de combustão.

Dos 53 (cinquenta e três) sítios arqueológicos identificação e cadastros, 5 (cinco) estão localizados no municípios de Parelhas e 48 (quarenta e oito) em Carnaúba dos Dantas. Desses, 29 (vinte e nove) estão integrados ao CNSA (Cadastro Nacional de Sítios Arqueológicos) e constam no cadastro do IPHAN.

Dos sítios identificados, 45 (quarenta e cinco) são sítios com grafismos rupestres, apresentando diferentes graus de complexidade gráfica. Alguns são passiveis de escavação para a visualização de contextos de integração arqueológica, ambiental e gráficas; enquanto os demais, por estarem em afloramento rochoso, no interior de cursos d'água ou terem apresentado sedimentos bastante perturbados, estão restritos aos componentes ambientais e gráficos.

Para efeito de uma melhor caracterização desses sítios, eles foram divididos segundo os seguintes critérios do protocolo descritivo, onde contam dados: Caracterização do Suporte Rochoso (posição, tipo de rocha, e inserção no relevo); Caracterização dos grafismos rupestres (dimensões temáticas, cenográficas e técnicas); Estado de conservação.

No descritor Caracterização do Suporte Rochoso observou-se nos sítios identificados o posicionamento tanto vertical (Figura 5) quanto horizontal (Figura 6) do suporte utilizado para a prática rupestres, sendo este último utilizado muito mais em função das gravuras. 


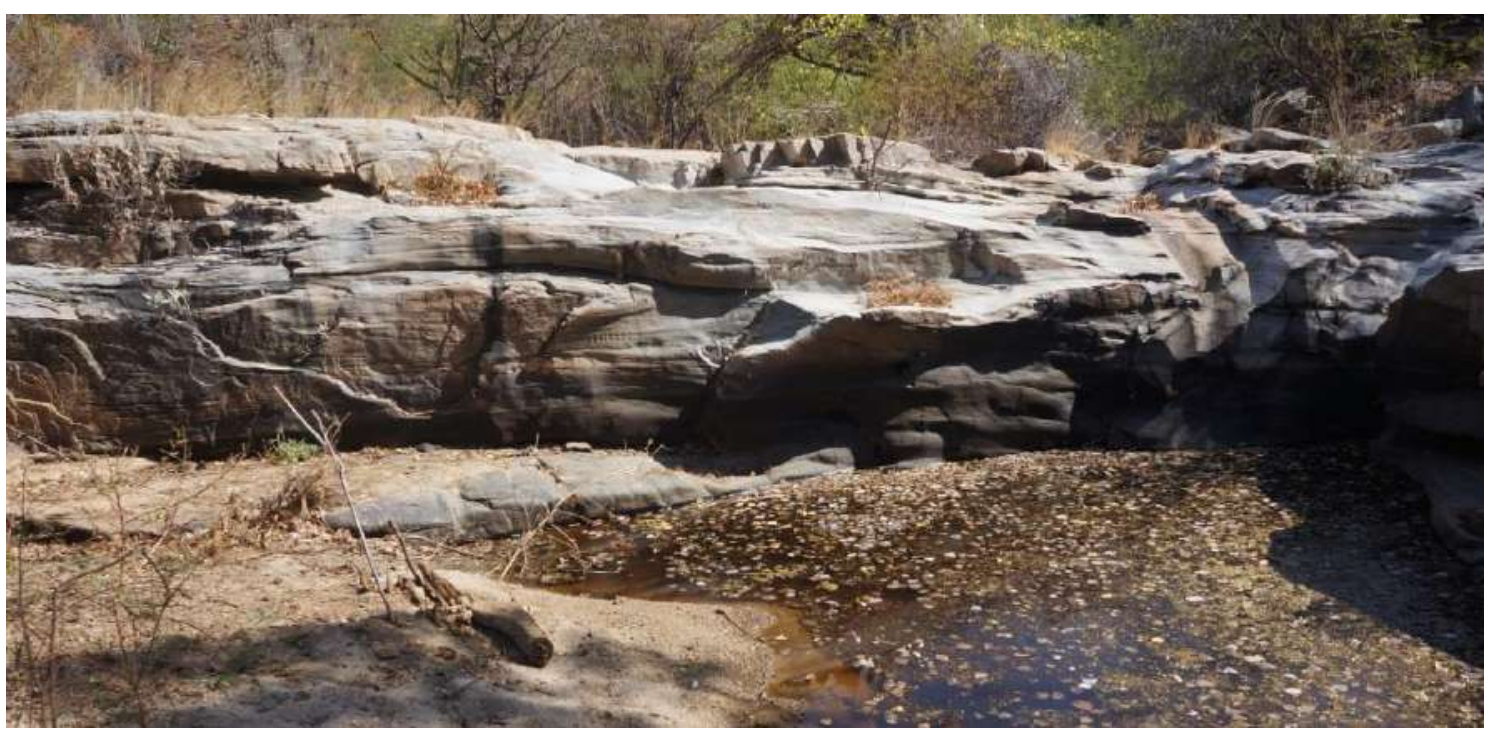

Figura 05: Sítio Poço do Caramuru. Afloramento horizontal, suporte de gravuras rupestres. Carnaúba dos Dantas - RN. Fonte: C\&M Arqueologia, 2016.

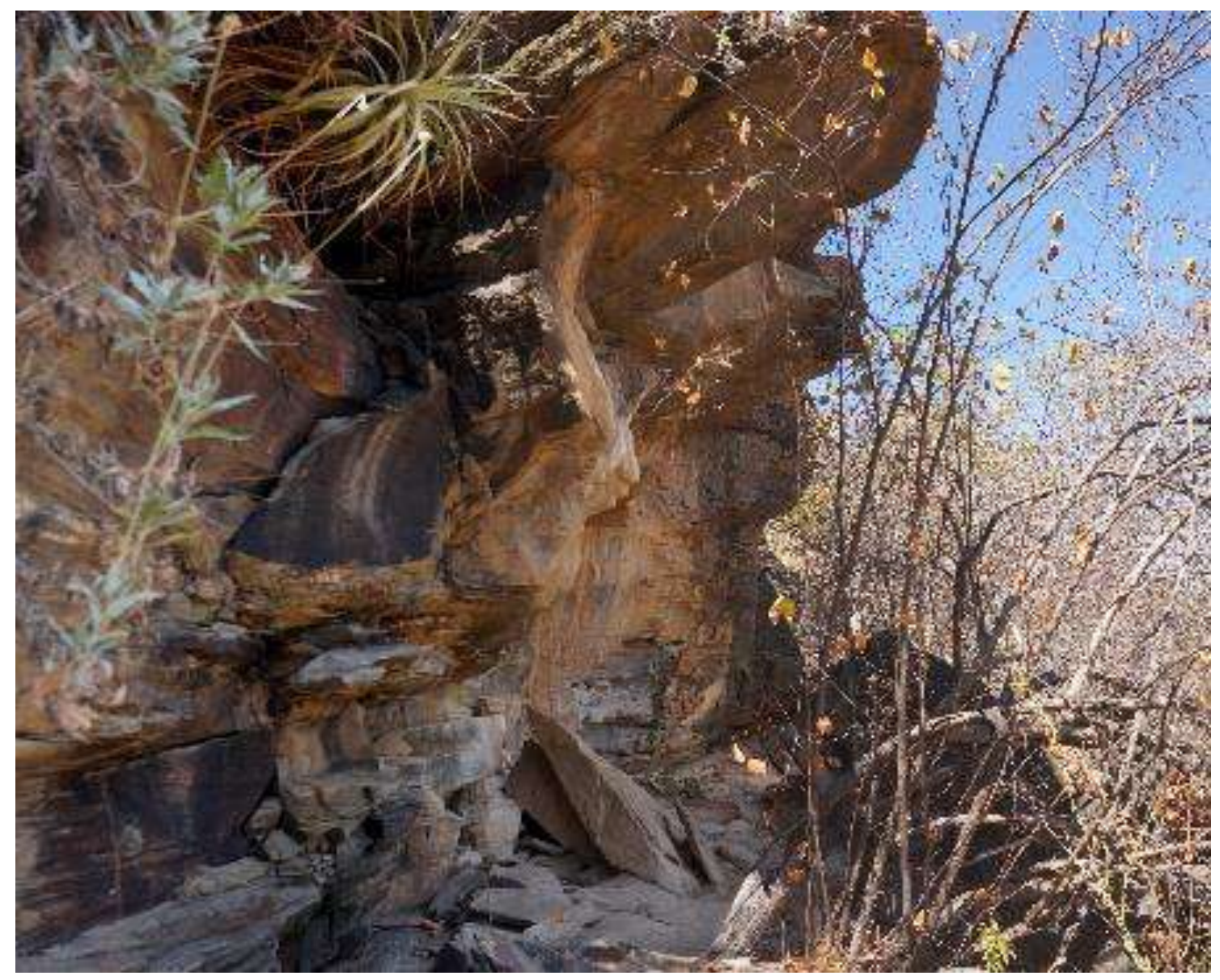

Figura 06: Sítio Casa Santa. Vista parcial do Abrigo, afloramento vertical. Carnaúba dos Dantas - RN. Fonte: C\&M Arqueologia, 2016. 
Relatório das Referências Culturais e Arqueológicas da Área de Abrangência do Sistema Adutor Seridó - Trecho Parelhas / Carnaúba dos Dantas RN- Brasil

A caracterização litológica prendeu-se, unicamente, a identificação macroscópica do tipo de rocha que foi utilizada como suporte. Na área prospectada foram observadas 4 (quatro) tipos de rochas: quartzitos, granitoides, gnaisse e micaxisto, distribuídos nos afloramentos rochosos horizontais e verticais e utilizados para a prática rupestre.

Quanto a inserção dos sítios no relevo, observa-se uma tendência dos mesmos com pinturas posicionados em média vertentes e os com gravuras em baixa vertente.

A caracterização gráfica dos registros rupestres, pintados e gravados, foi realizada à luz de três categorias analíticas distintas, porém inter-relacionadas: Dimensão Temática $^{4}$; Dimensão Cenográfica ${ }^{5}$; e a Dimensão Técnica ${ }^{6}$;

Quanto a Temática dos grafismos foram instituídas as seguintes variáveis observacionais: grafismos reconhecíveis e não reconhecíveis.

Em relação aos grafismos reconhecíveis pode ser identificado no conjunto rupestre observado 2 (duas) classes: zoomorfo e antropomorfo. Na categoria zoomorfo observa-se a presença de cervídeos e aves em sua maioria. Na categoria antropomorfo foram observados os indivíduos com atributos culturais associados, a exemplo dos cocares ou objetos de mão, esses antropomorfos podem aparecer isolados ou em conjuntos (situação dominante, Figura 07).

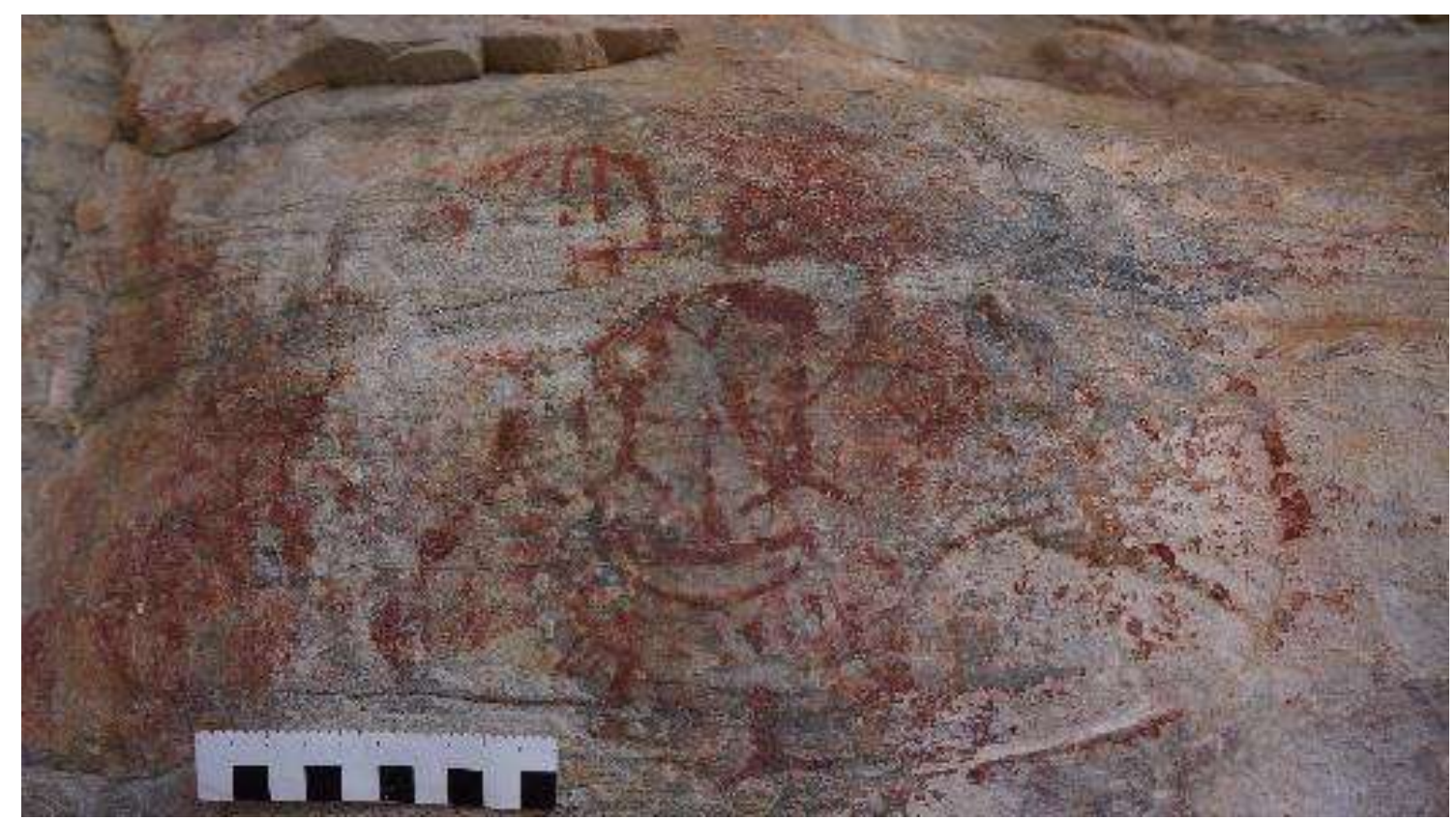

Figura 07: Sítio Casa Santa. Detalhe das figuras antropomorfas formando cena hermética. Carnaúba dos Dantas RN. Fonte: C\&M Arqueologia, 2016.

4 A dimensão temática prende-se ao exame do tema representado e seus elementos constitutivos.

5 A dimensão cenográfica analisa a forma como os elementos componenciais são representados e distribuídos no espaço gráfico;

6 A dimensão técnica trata dos aspectos relativos aos processos de escolha do suporte e do tratamento (ou não) dispensado ao mesmo, a espessura dos instrumentos utilizados na realização gráfica e a espessura dos traços com os quais foram representados os elementos do mundo natural ou cultural. 
Quanto aos grafismos não reconhecíveis, foi observado a presença de grafismos puros simples com morfologia que remete a zigue-zague, círculos simples e concêntricos, aspirais, grades, tridígitos e os pontos sequenciais ou pontiformes; e grafismos puros mais elaborados apresentando conjuntos de linhas e figuras em composições singulares (figuras 08 e 09).

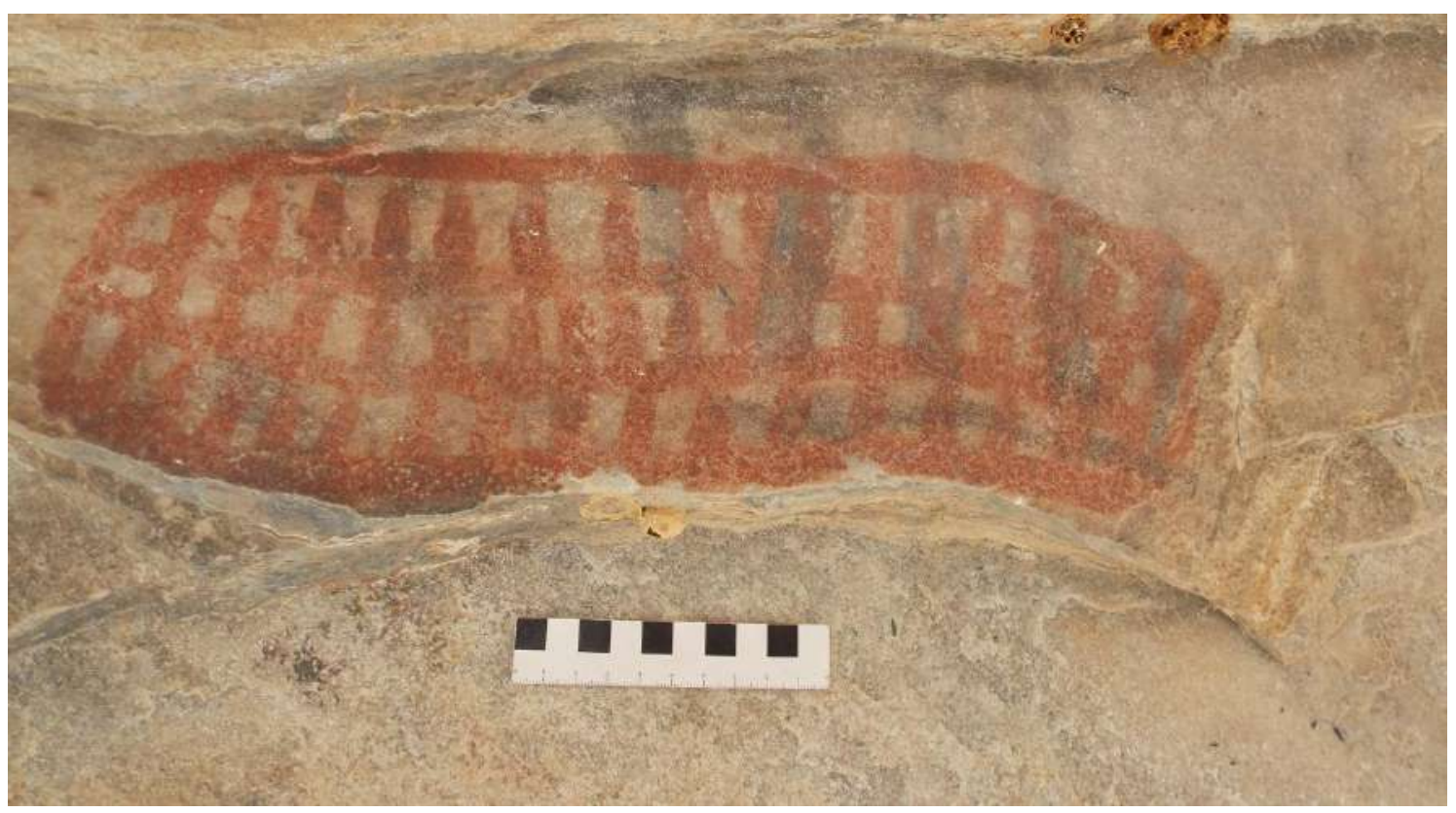

Figura 08: Sítio Pedra do Letreiro. Representação de grafismo puro. Carnaúba dos Dantas - RN. Fonte: C\&M Arqueologia, 2016.

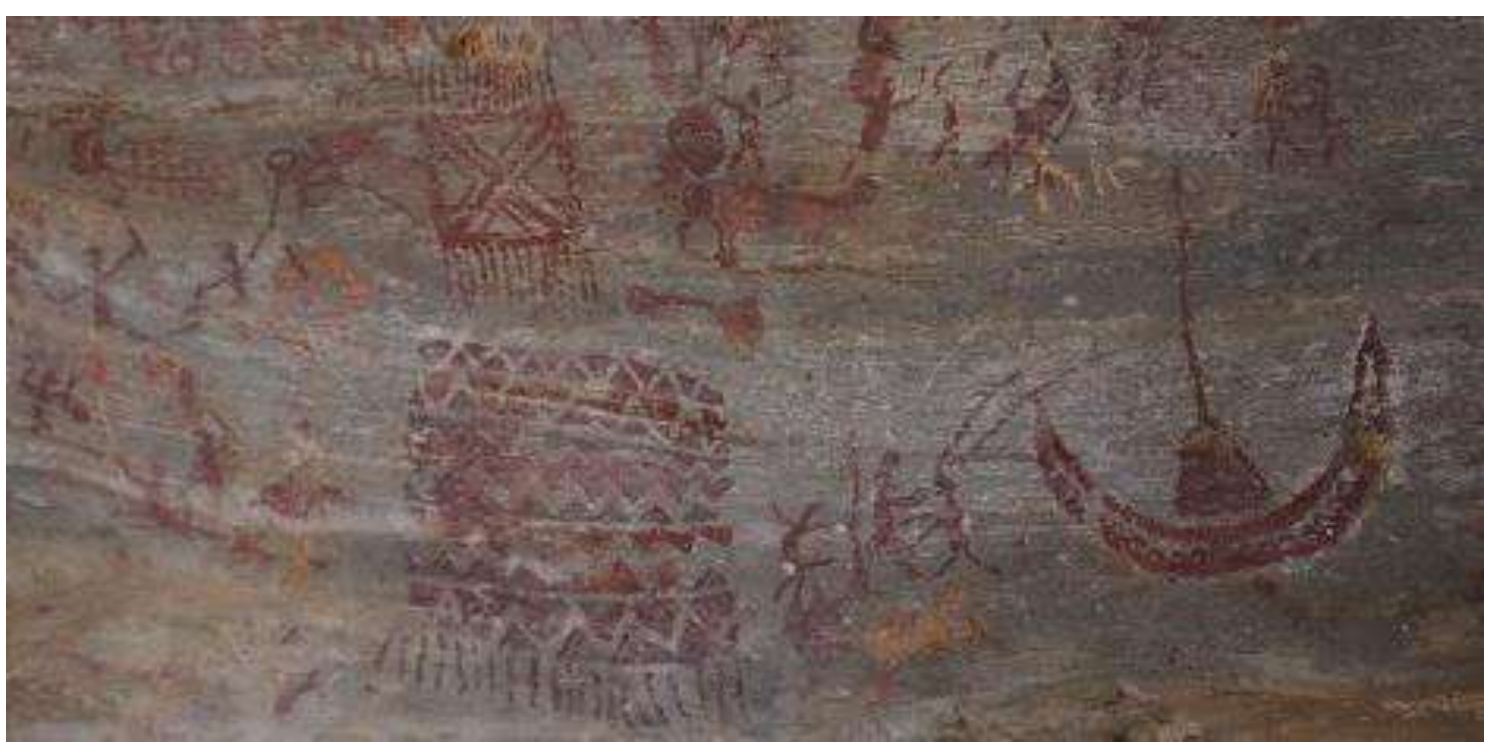

Figura 09: Sítio Casa Santa. Detalhe de grafismos puros mais elaborados. Carnaúba dos Dantas-RN. Fonte: C\&M Arqueologia, 2016.

Quanto à cenografia pode-se observar nas pinturas identificadas figuras em composição formando cenas, que podem ser identificadas como herméticas, lúdicas, sexo ou de caça (Figura 10). Essas figuras apresentam-se de forma dinâmica. 


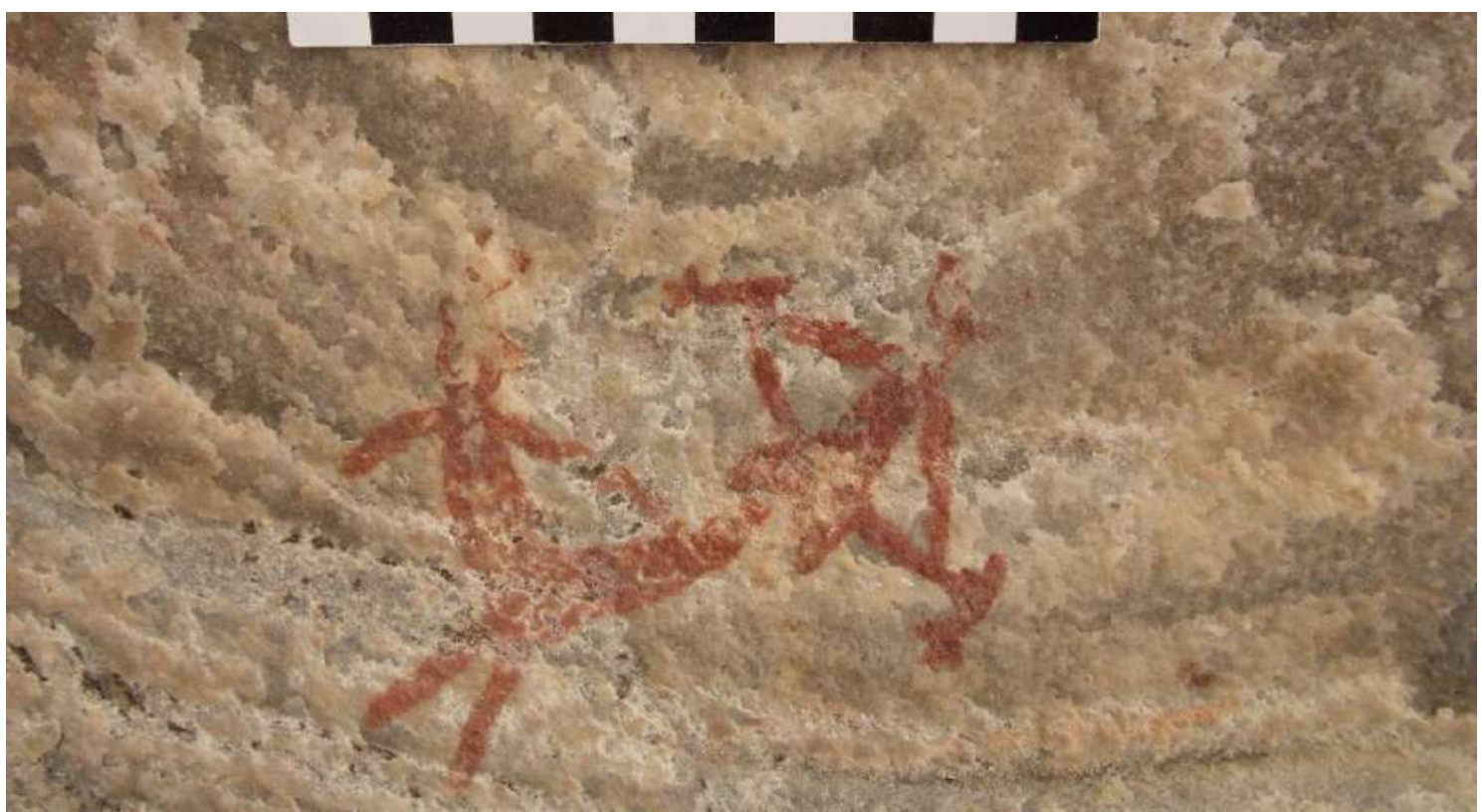

Figura 10: Sítio Xique xique II. Cena de sexo. Carnaúba dos Dantas-RN. Fonte: C\&M Arqueologia, 2016.

Quanto ao preenchimento observa-se que a dominância aponta para o preenchimento total das figuras, são recessivas com preenchimento parcial ou sem preenchimento (Figura 11).

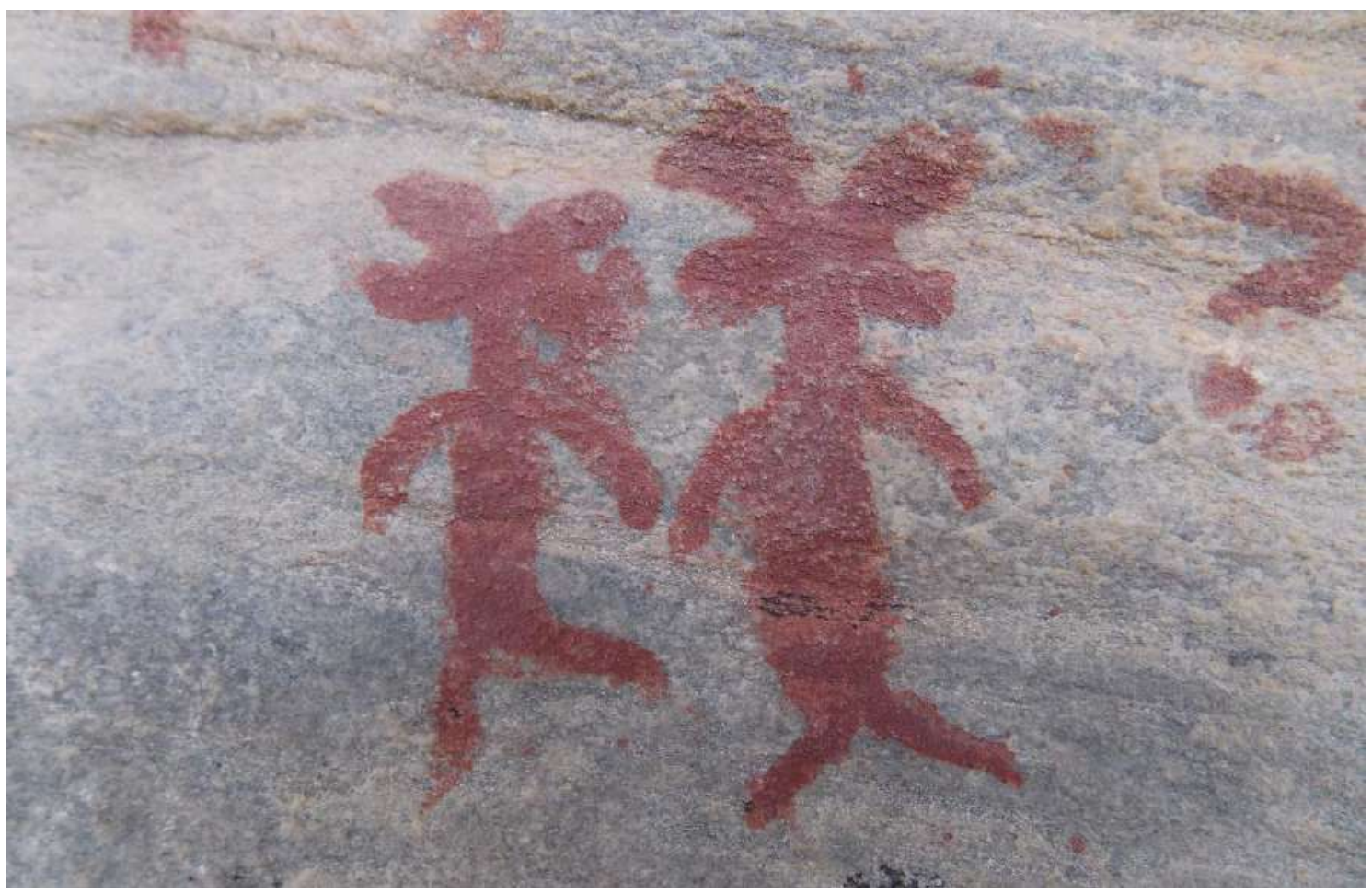

Figura 11: Sítio Xique-Xique 4. Detalhe antropomorfos em cenas herméticas, com preenchimento total e na cor vermelha. Carnaúba dos Dantas - RN. Fonte: C\&M Arqueologia, 2016.

Quanto a cor observa-se no conjunto gráficos dos sítios identificados painéis de dominância monocrômica, com predomínio da cor vermelha em diferentes tonalidades. Essa diferença de 
nuances da cor vermelha pode ser resultado da composição da tinta e/ou alterações tafonômicas. Em alguns sítios pode ser observado grafismos nas cores amarela, preta e branca (Figura 12).

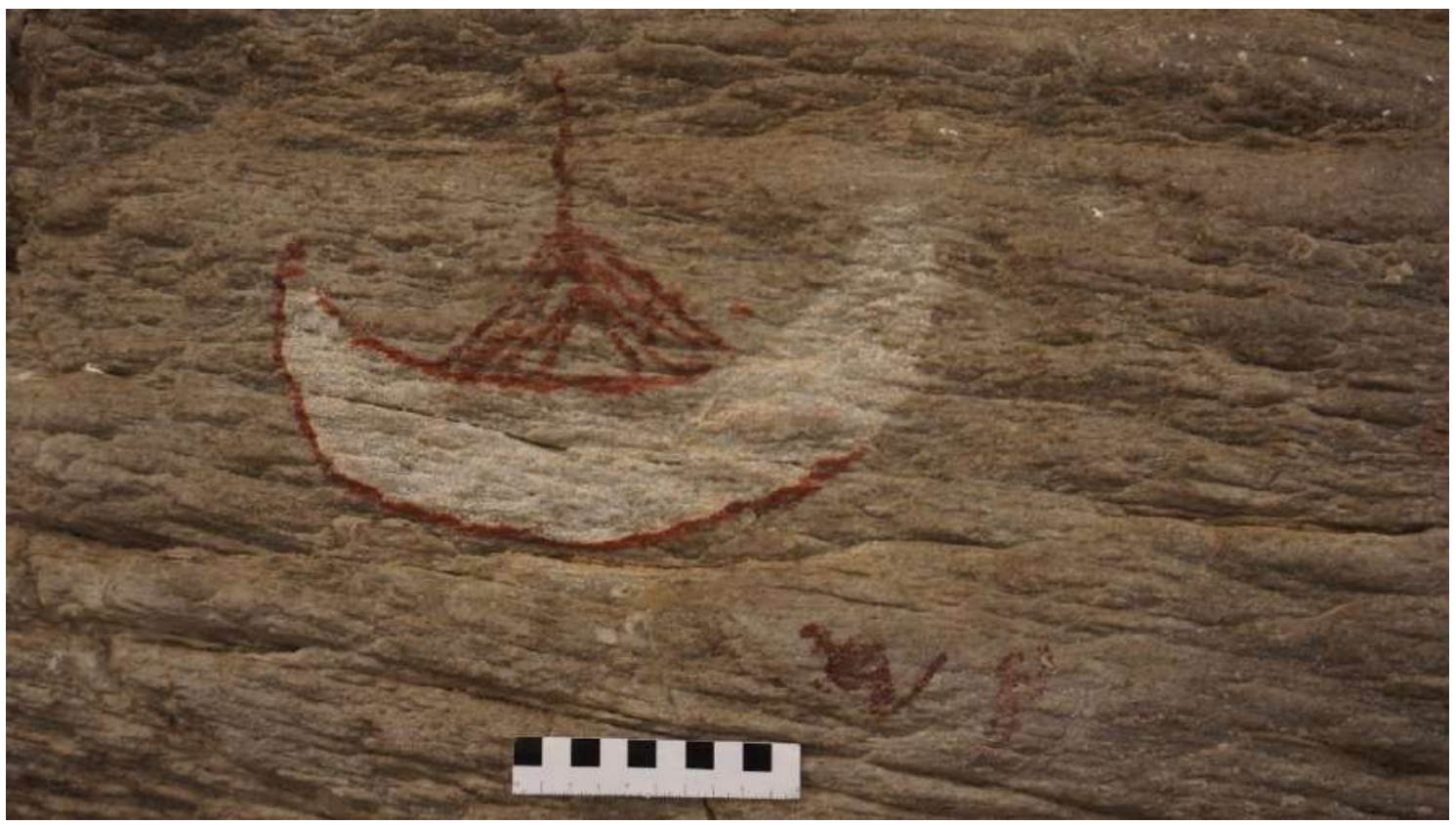

Figura 12: Sítio Furna do Messias. Detalhe de figuras em bicromia. Carnaúba dos Dantas - RN. Fonte: C\&M Arqueologia, 2016.

Para caracterização da Dimensão Técnica foram instituídas duas variáveis: uma ligada ao exame da rocha, na busca de vestígios que possam indicar algum tipo de tratamento antes de sua utilização como suporte gráfico; a outra voltada para a verificação da espessura dos traços. Não foram identificados no conjunto gráfico apresentado, tratamento prévio do suporte para as pinturas rupestres. Quanto a espessura do traço, observa-se uma preferência por um traçado fino $(0,5$ a $1 \mathrm{~cm})$ e contínuo (Figura 13).

Quanto a caracterização gráfica das gravuras foram observados os mesmos critérios das pinturas, quando pertinentes.

Em relação à temática, domina nas gravuras os grafismos puros com morfologia variada que remete a zigue-zague, círculos simples e círculos concêntricos, aspirais, tridígitos e os pontos sequenciais e cúpules (Figura 14). 


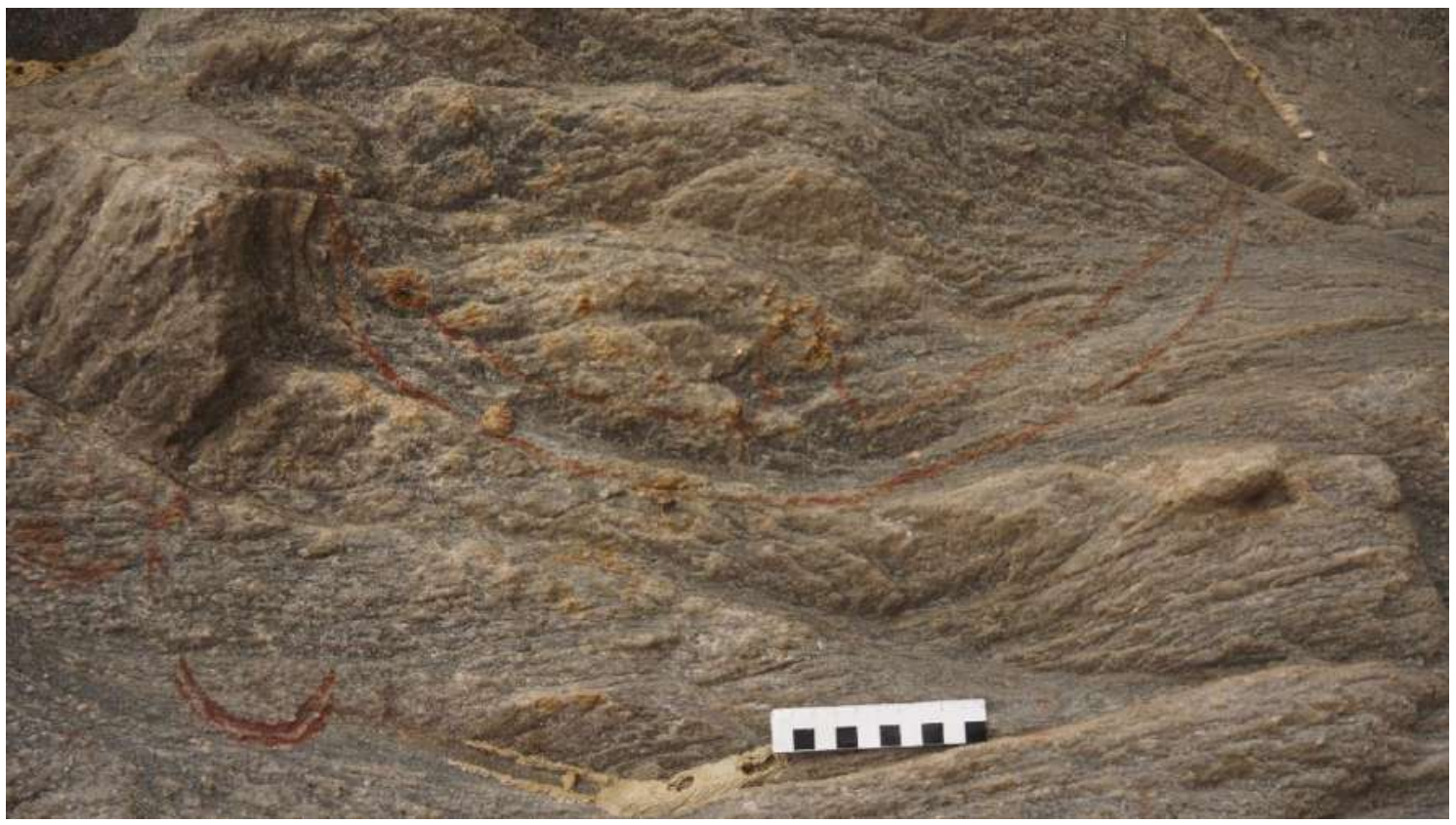

Figura 13: Sítio Furna do Messias. Detalhe da espessura do traço que forma a figura. Carnaúba dos Dantas - RN. Fonte: C\&M Arqueologia, 2016.

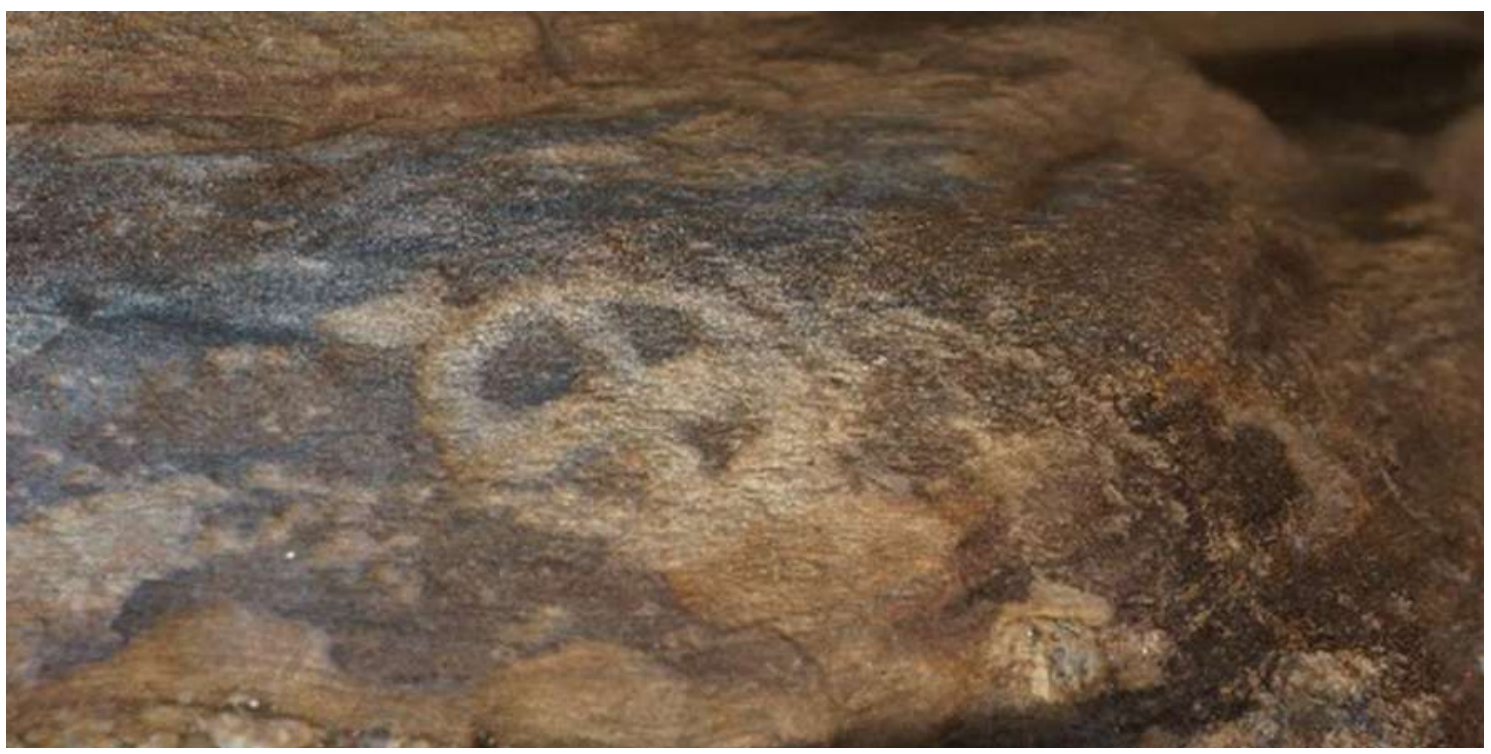

Figura 14: Sítio Fundões II. Detalhe dos grafismos puros em círculos tetrapartidos. Carnaúba dos Dantas - RN. Fonte: C\&M Arqueologia, 2016.

Quanto à cenografia pode-se observar que gravuras formam composições muito próximas umas a outras formando conjuntos dentro do espaço gráfico (Figura 15). A técnica de execução dominante é o picoteado seguido de raspagem. Os sulcos são rasos, mas largos, realizados em forma de $U$. $O$ tamanho das gravuras tem dominância entre $10 \mathrm{~cm}$ e $25 \mathrm{~cm}$ de comprimento. 


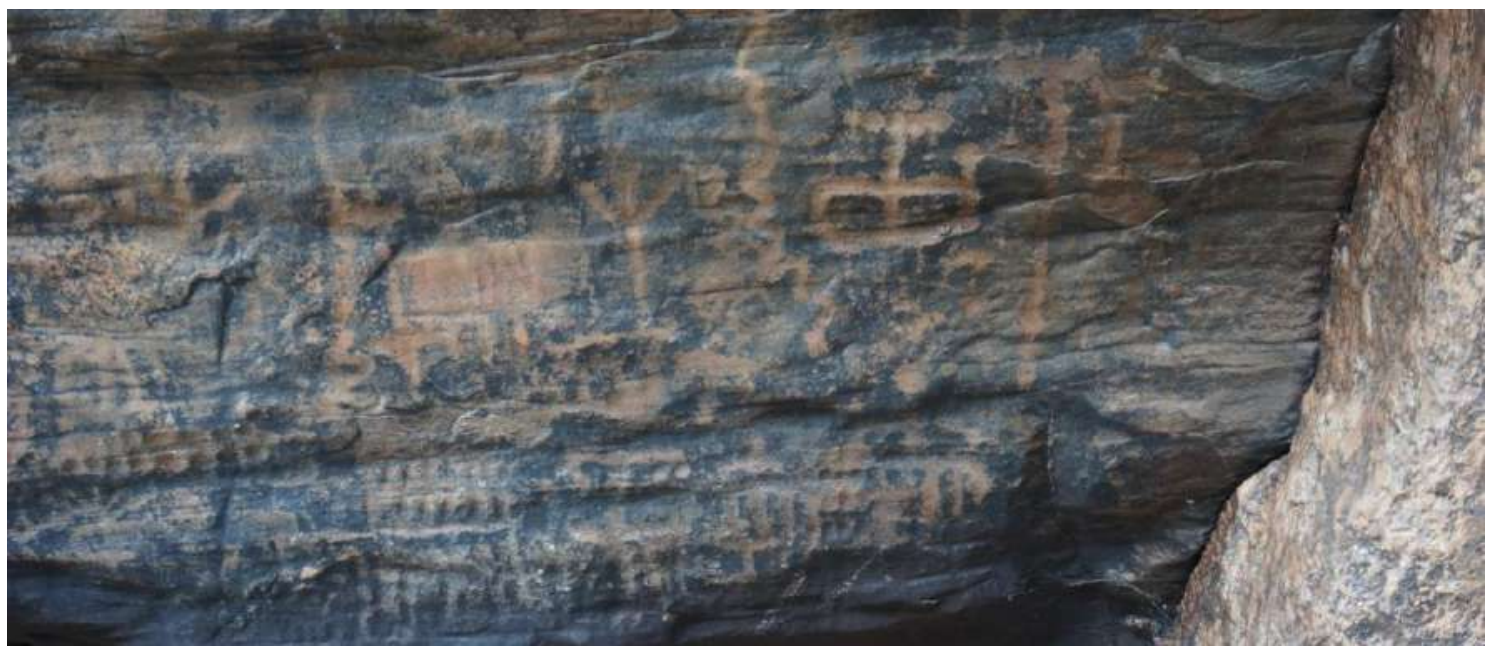

Figura 15: Sítio Fundões II. Alta concentração de grafismos puros. Carnaúba dos Dantas - RN. Fonte: C\&M Arqueologia, 2016.

Foi observado em alguns sítios, como no Cachoeira do Letreiro e Casa de Pedra um tratamento prévio em pintura antes da execussão da gravura que, em alguns caso, foram também pintadas (Figuras 16 e 17).

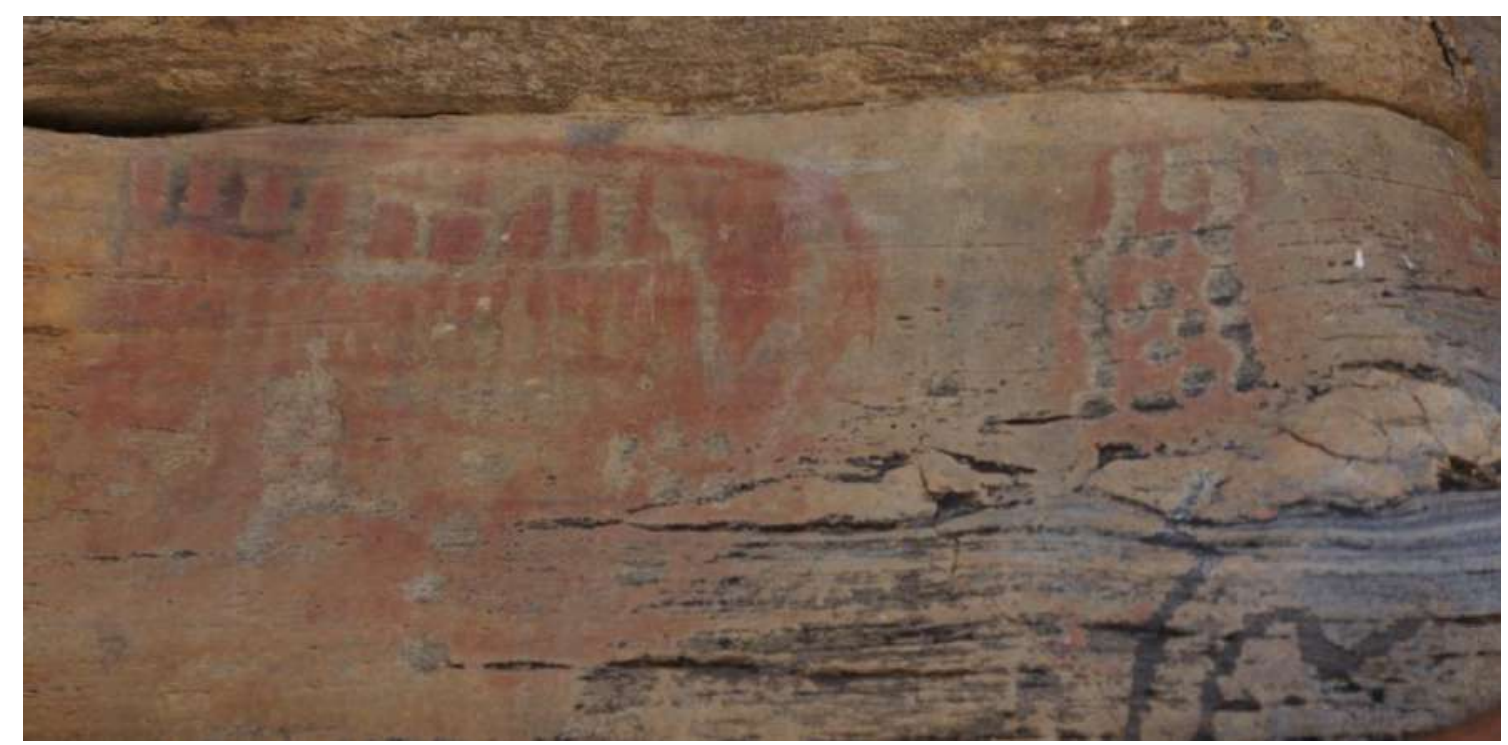

Figura 16: Sítio Cachoeira do Letreiro. Detalhe pintura e gravura. Carnaúba dos Dantas - RN. Fonte: C\&M Arqueologia, 2016. 


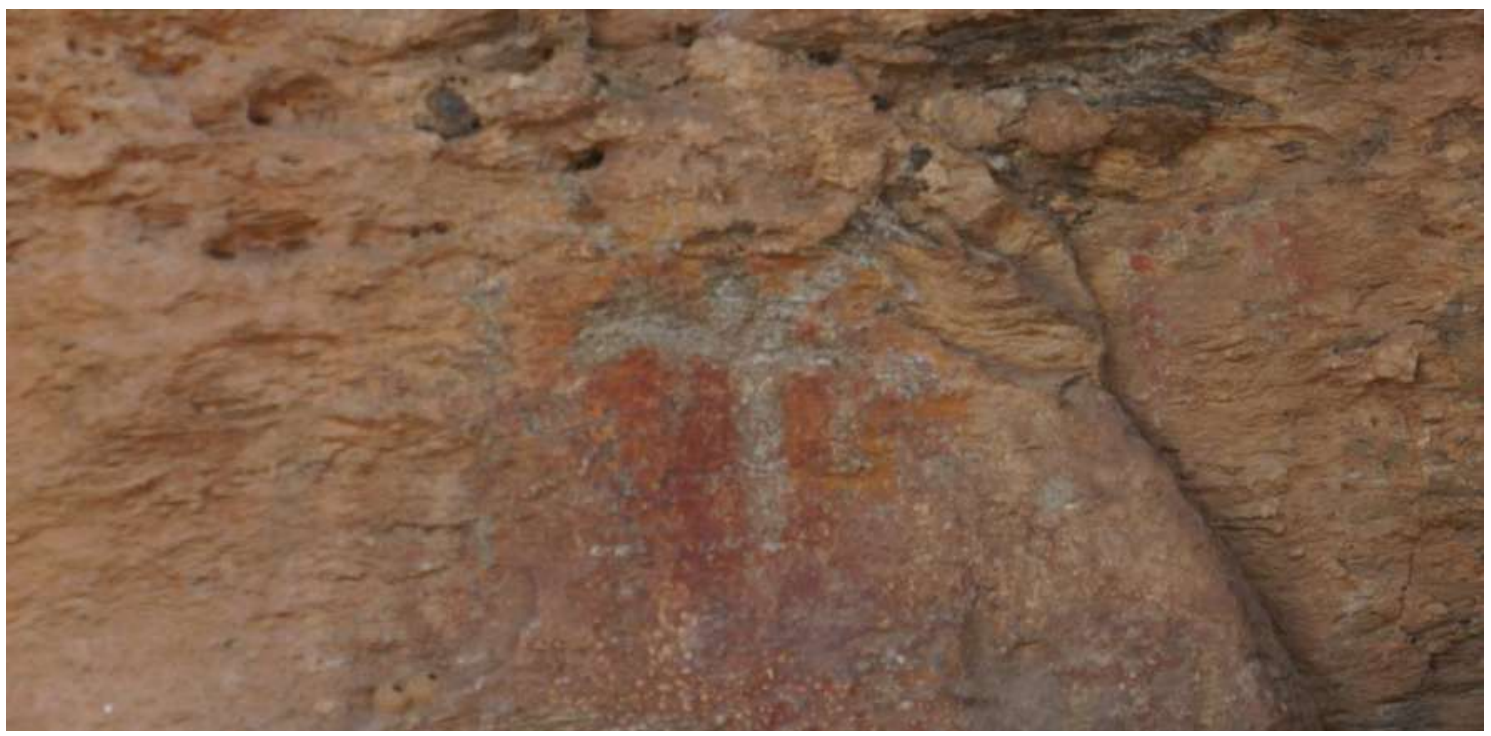

Figura 17: Sítio Casa de Pedra. Detalhe do suporte preparado para execução da gravura. Carnaúba dos Dantas - RN. Fonte: C\&M Arqueologia, 2016.

No quesito Estado de Conservação a caracterização ateve-se as formas de intemperismos que, de maneira mais direta, pudessem impactar os grafismos, trazendo prejuízo à longevidade dos mesmos. Assim, do ponto de vista da conservação foram consideradas três importantes classes intempéricas: a físico-química, como a dissolução da rocha, a esfoliação ou desplacamento, depósito de sais e manchas de água sobre a superfície da rocha (Figura 18); a termo-tectônica, como a rachadura; e a biológica, marcada pela presença de insetos, raízes e microrganismos. 0 córtex rochoso dos sítios evidenciados na área estão bastante desgastados, o que compromete a visualização dos grafismos e ocasiona o desaparecimento do patrimônio cultural rupestre na região.

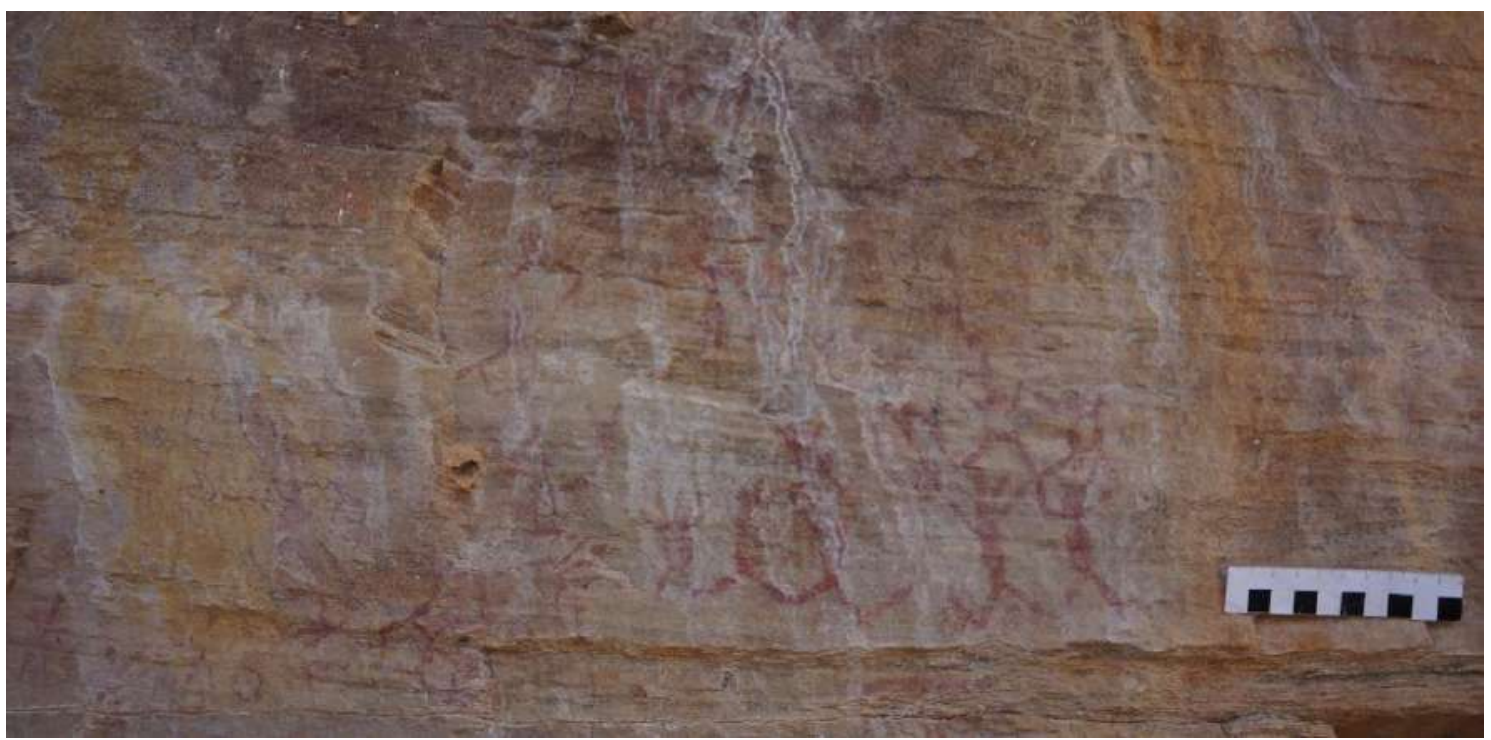

Figura 18: Sítio Casa Santa. Mancha d’água sobre as pinturas. Carnaúba dos Dantas - RN. Fonte: C\&M Arqueologia, 2016. 
Ações antrópicas como vandalismos e pichações não são os fatores de degradação mais recorrentes na área, mas é necessário atuar no sentido de mitiga-los para que não venham a se tornar imperativo para a destruição dos sítios (Figura 19). As ações secundárias resultantes da caça indiscriminada e do desmatamento da vegetação foi o fator aparentemente preponderante para o avanço dos danos físico-químicos evidenciados nos sítios.

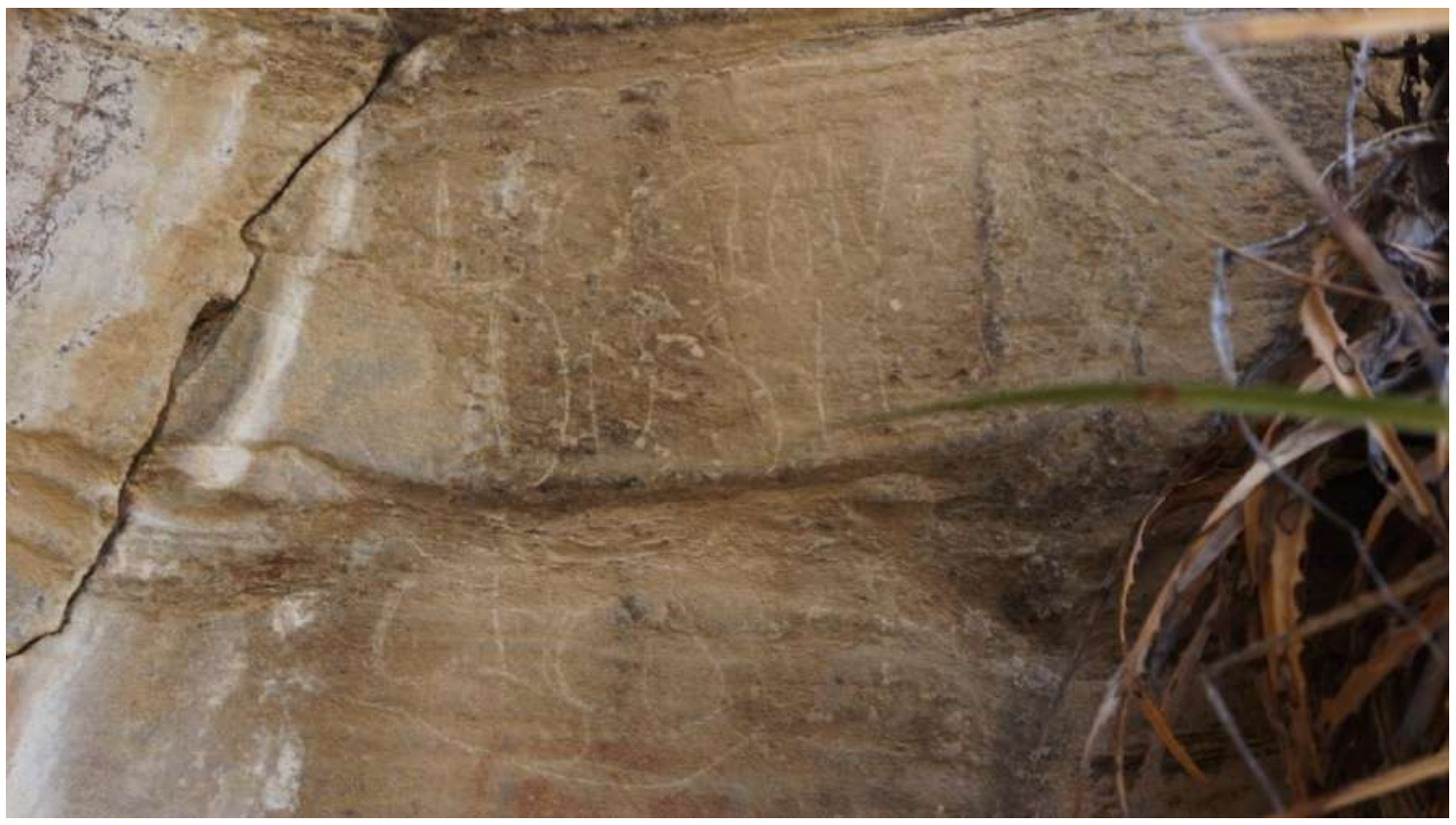

Figura 19: Sítio Cachoeira do Letreiro. Vandalismo. Inscrições de nomes gravados. Carnaúba dos Dantas RN. Fonte: C\&M Arqueologia, 2016.

No que concerne aos sítios a céu aberto, foram identificados 8 (oito) na área prospectada. Esses sítios arqueológicos caracterizam-se por grandes concentrações de vestígios líticos, cerâmicos e estruturas de combustão.

Quanto ao contexto ambiental observou-se que estão localizados em área com elevado gradiente de ravinas (Figura 20), resultando em alterações no terreno e possibilitando o transporte horizontal dos vestígios de superfície.

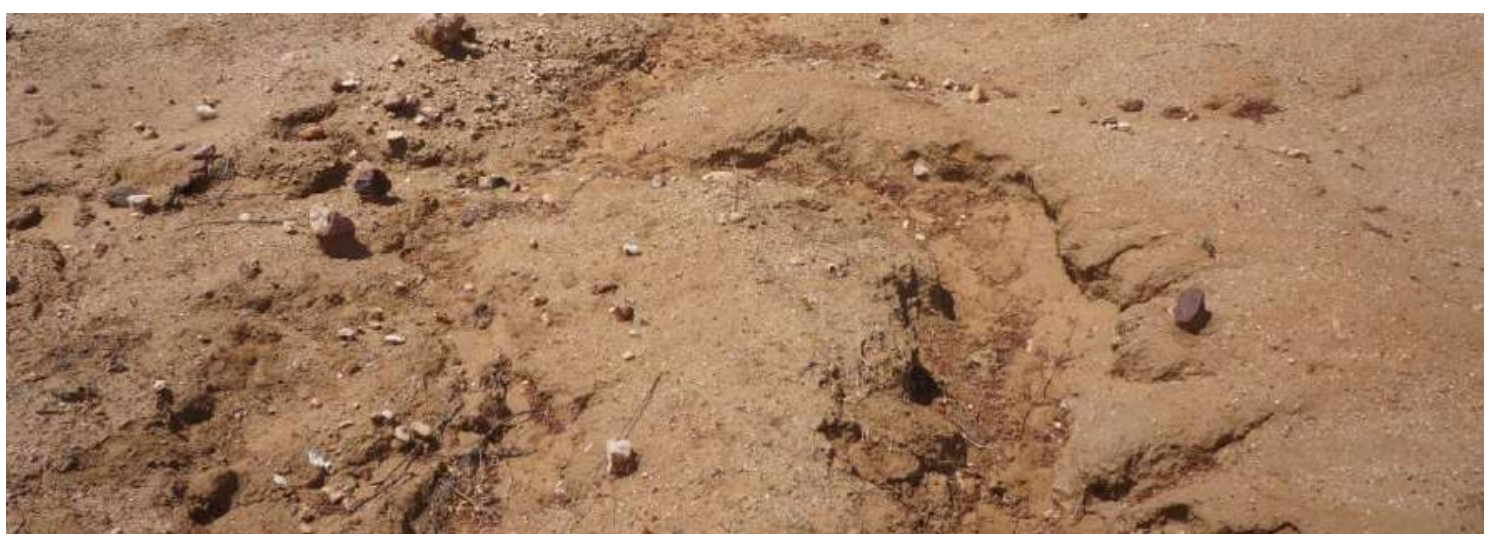

Figura 20: Sítio Lajedo. Ravinas. Carnaúba dos Dantas - RN. Fonte: C\&M Arqueologia, 2016. 
Relatório das Referências Culturais e Arqueológicas da Área de Abrangência do Sistema Adutor Seridó - Trecho Parelhas / Carnaúba dos Dantas RN- Brasil

\section{Referências}

DOMINGO, I. BURKE, H; SMITH, C. Manual de Campo Para Arqueologos. Barcelona: Ariel Editorial, 2007.

CAVIGNAC, J. A. Os Filhos de Tereza: narrativas e religiosidade na Boa Vista dos Negros / RN. In: TOMO, Revista do Núcleo de Pós-Graduação e pesquisa em Ciências Sociais UFS, n. 11, Jul. - dez. 2007. p. 77102.

SANTOS, J. M. D. Religiosidade e espaço: a construção do povoado Santo Antônio - Cobra - Parelhas RN. Monografia (Bacharelado em História). Caicó, Universidade

BRASIL. Instrução Normativa № 125, de 18 de outubro de 2006. Estabelece os procedimentos para implantação de recifes artificiais no âmbito da gestão dos recursos pesqueiros. Diário Oficial da República Federativa do Brasil, Brasília, DF, n. 58, 23 out. 2006. Seção I, p. 84. 